\title{
Therapeutic Cancer Vaccines: Past, Present and Future
}

\author{
Chunqing Guo ${ }^{1,3,4}$, Masoud H. Manjili2,4, John R. Subjeck ${ }^{5}$, Devanand Sarkar ${ }^{1,3,4}$, Paul B. \\ Fisher $^{1,3,4}$, and Xiang-Yang Wang $1,3,4,{ }^{*}$ \\ 1Department of Human \& Molecular Genetics, Virginia Commonwealth University School of \\ Medicine, Richmond, VA23298, USA \\ ${ }^{2}$ Department of Microbiology \& Immunology, Virginia Commonwealth University School of \\ Medicine, Richmond, VA23298, USA \\ ${ }^{3} \mathrm{VCU}$ Institute of Molecular Medicine, Virginia Commonwealth University School of Medicine, \\ Richmond, VA23298, USA \\ ${ }^{4}$ VCU Massey Cancer Center, Virginia Commonwealth University School of Medicine, Richmond, \\ VA23298, USA \\ ${ }^{5}$ Department of Cell Stress Biology, Roswell Park Cancer Institute, Buffalo, NY 14263, USA
}

\section{Abstract}

Therapeutic vaccines represent a viable option for active immunotherapy of cancers that aim to treat late stage disease by using a patient's own immune system. The promising results from clinical trials recently led to the approval of the first therapeutic cancer vaccine by the U.S. Food and Drug Administration. This major breakthrough not only provides a new treatment modality for cancer management, but also paves the way for rationally designing and optimizing future vaccines with improved anticancer efficacy. Numerous vaccine strategies are currently being evaluated both pre-clinically and clinically. This review discusses therapeutic cancer vaccines of diverse platforms or targets as well as the preclinical and clinical studies employing these therapeutic vaccines. We will also consider tumor-induced immune suppression that hinders the potency of therapeutic vaccines, and potential strategies to counteract these mechanisms for generating more robust and durable antitumor immune responses.

\section{Keywords}

cancer vaccine; immunotherapy; tumor-associated antigen; immune modulator; immunosuppression; tumor microenvironment

\section{Introduction}

Unlike prophylactic vaccines that are generally administered to healthy individuals, therapeutic cancer vaccines are administrated to cancer patients and designed to eradicate cancer cells through strengthening patient's own immune responses (Lollini et al., 2006). The various immune effector mechanisms mobilized by therapeutic vaccination specifically attack and destroy cancer cells and spare normal cells. Thus, therapeutic cancer vaccines, in principle, may be utilized to inhibit further growth of advanced cancers and/or relapsed

\footnotetext{
*Correspondence: Xiang-Yang Wang, Department of Human \& Molecular Genetics, PO Box 980033, Virginia Commonwealth University School of Medicine, Richmond, VA 23298. Tel: (804) 628-2679; Fax: (804) 628-1194; xywang@ vcu.edu..

Conflict of interest statement: The authors declare no conflict of interest
} 
tumors that are refractory to conventional therapies, such as surgery, radiation therapy and chemotherapy.

In 1891, Dr. William Coley made the first attempt to stimulate the immune system for improving a cancer patient's condition by intratumoral injections of inactivated Streptococcus pyogenes and Serratia marcescens (Coley's Toxin) (McCarthy, 2006). The idea came from the observation of spontaneous remissions of sarcomas in rare-cancer patients who had developed erysipelas. Despite his reported effective responses in patients, his work was viewed with skepticism by the scientific community. Todays, the field of immunology has developed into a highly sophisticated specialty, and the modern science of immunology has shown that Coley's principles were correct. Indeed, the bacillus cametteguerin (BCG) that is one similar example as the Coley's Toxin, is still being used intravesically to treat superficial bladder cancer (Lamm et al., 1991; Morales et al., 1976; van der Meijden et al., 2003).

Despite considerable efforts to develop cancer vaccines, the clinical translation of cancer vaccines into efficacious therapies has been challenging for decades. Nonetheless, the U.S. Food and Drug Administration (FDA) have approved two prophylactic vaccines, including one for hepatitis B virus that can cause liver cancer and another for human papillomavirus accounting for about $70 \%$ of cervical cancers. More encouragingly, recent advances in cancer immunology have achieved clinical proof-of-concept of therapeutic cancer vaccine. Sipuleucel-T, an immune cell based vaccine, for the first time, resulted in increased overall survival in hormone-refractory prostate cancer patients. This led to FDA approval of this vaccine with the brand name Provenge (Dendreon) in 2010 (Cheever and Higano, 2011).

Although the challenge of developing an effective cancer vaccine remains (Schreiber et al., 2011; Zhou and Levitsky, 2012), many diverse therapeutic vaccination strategies are under development or being evaluated in clinical trials. Based on their format/content, they may be classified into several major categories, which include cell vaccines (tumor or immune cell), protein/peptide vaccines, and genetic (DNA, RNA and viral) vaccines. In this review, we present a synopsis of the history of research in the field of therapeutic cancer vaccines as well as current state of vaccine therapeutics for treatment of human cancers. In addition, the obstacles for effective cancer vaccine therapy are also discussed in order to provide future directions for improvement and optimization of cancer vaccines.

\section{Tumor cell vaccines}

\section{A. Autologous tumor cell vaccines}

Autologous tumor vaccines prepared using patient-derived tumor cells represent one of the first types of cancer vaccines to be tested (Hanna and Peters, 1978). These tumor cells are typically irradiated, combined with an immunostimulatory adjuvant (e.g., BCG), and then administered to the individual from whom the tumor cells were isolated (Berger et al., 2007; Harris et al., 2000; Maver and McKneally, 1979; Schulof et al., 1988). Autologous tumor cell vaccines have been tested in various cancers, including lung cancer (Nemunaitis, 2003; Ruttinger et al., 2007; Schulof et al., 1988), colorectal cancer (de Weger et al., 2012; Hanna et al., 2001; Harris et al., 2000; Ockert et al., 1996), melanoma (Baars et al., 2002; Berd et al., 1990; Mendez et al., 2007), renal cell cancer (Antonia et al., 2002; Fishman et al., 2008; Kinoshita et al., 2001) and prostate cancer (Berger et al., 2007). One major advantage of whole tumor cell vaccines is its potential to present the entire spectrum of tumor-associated antigens to the patient's immune system. However, preparation of autologous tumor cell vaccines requires sufficient tumor specimen, which limits this technology to only certain tumor types or stages. 
Autologous tumor cells may be modified to confer higher immunostimulatory characteristics. Newcastle disease virus (NDV)-infected autologous tumor cells were shown to induce tumor protective immunity in multiple animal tumor models, such as ESb lymphoma and B16 melanoma (Heicappell et al., 1986; Plaksin et al., 1994). Clinical trials demonstrated that these modified tumor cells were safe and had a positive effect on antitumor immune memory in cancer patients (Karcher et al., 2004; Ockert et al., 1996; Schirrmacher, 2005; Steiner et al., 2004). Immunization with tumor cells engineered to express IL-12, a key cytokine promoting Th1 immunity, also resulted in strong tumor suppression in mice accompanied by high IFN- $\gamma$ production and increased activation of cytotoxic T lymphocyte (CTL) and natural killer (NK) cells (Asada et al., 2002). In a recent phase II trial, treatment with renal cell carcinoma transduced with co-stimulatory molecule B7-1 showed promising antitumor effect, as indicated by $3 \%$ pathologic complete response, $5 \%$ partial response, 64\% stable disease and median survival of 21.8 months (Fishman et al., 2008).

GM-CSF-transduced autologous tumor cell vaccines (GVAX) have been extensively studied in preclinical and clinical studies (Armstrong et al., 1996; Dong et al., 1998; Dranoff et al., 1993a; Dranoff et al., 1997; Dunussi-Joannopoulos et al., 1998; Levitsky et al., 1996; Sampson et al., 1996; Soiffer et al., 2003; Soiffer et al., 1998; Wakimoto et al., 1996). Mechanistic studies showed that GVAX recruits dendritic cells (DCs) for presentation of tumor antigens and priming of $\mathrm{CD}^{+} \mathrm{T}$ cells (Dranoff et al., 1993b; Mach et al., 2000). GVAX also stimulates the maturation of DCs by upregulating B7-1 expression (Dranoff, 2002; Mach et al., 2000). Immunization with GVAX, when combined with blockade of CTL-associated antigen 4 (CTLA-4), an immune checkpoint inhibitor (Leach et al., 1996), promotes the rejection of established murine melanoma by altering the balance of $\mathrm{T}$ effector cells (Teff) and T regulatory cells (Treg) (Quezada et al., 2006; van Elsas et al., 1999). Enhanced antitumor efficacy was evident when tumor cell vaccine engineered to express Flt3 ligand (FVAX) was combined with blockade of CTLA4 for the treatment of TRAMP prostate adenocarcinomas (Curran and Allison, 2009). In addition to CTLA-4, the programmed death-1 (PD-1) interaction with its ligand PD-L1/L2 or B7-1 also inhibits T cell activation and cytokine production (Butte et al., 2007). Interestingly, combination blockade of PD-1 and CTLA-4 synergized with FVAX, but not GVAX, in controlling the outgrowth of pre-established B16 tumors (Curran et al., 2010), suggesting that blockade of negative costimulatory pathways favors the expansion of tumor-specific $\mathrm{T}$ cells and maintenance of their effector functions, resulting in shifting the immunosuppressive tumor microenvironment to an inflammatory/immunostimulatory state. Other than targeting negative immunoregulatory pathways, GVAX has been formulated with lipopolysaccharide (LPS), a TLR4 agonist, for the treatment of several murine tumors (Davis et al., 2011). Intratumoral administration of LPS-absorbed GVAX markedly improved an antitumor response in comparison with GVAX alone. This enhanced anti-tumor effect correlated with increased tumor infiltration by activated DCs as well as $\mathrm{CD} 8^{+}$and $\mathrm{CD} 4^{+} \mathrm{T}$ cells.

\section{B. Allogeneic tumor cell vaccines}

Allogeneic whole tumor cell vaccines, which typically contain two or three established human tumor cell lines, may be used to overcome many limitations of autologous tumor cell vaccines. These include limitless sources of tumor antigens, standardized and large-scale vaccine production, reliable analysis of clinical outcomes, easy manipulation for expression of immunostimulatory molecules and cost-effectiveness.

Canvaxin $^{\mathrm{TM}}$ vaccine is an allogeneic whole-cell vaccine consisting of three melanoma lines combined with BCG as an adjuvant (Morton et al., 1992). In a phase II trial, the median overall survival (OS) and 5 year rate of survival were significantly higher in stage III melanoma patients receiving Canvaxin ${ }^{\mathrm{TM}}$ as postoperative adjuvant therapy compared to 
control group (56.4 months and 49\% versus 31.9 months and $37 \%$; $p<0.001$ ) (Morton et al., 2002). In another phase II trial in patients with completely resected disseminated stage IV melanoma, treatment with Canvaxin ${ }^{\mathrm{TM}}$ resulted in a 39\% 5-year OS compared to the control arm $(20 \%)$ (Hsueh et al., 2002). However, two multi-institutional randomized phase III trials in patients with stage III and IV melanoma failed to achieve a determination of vaccine efficacy, and therefore, these trials were discontinued (Sondak et al., 2006).

The clinical activity of allogeneic GVAX vaccine has been evaluated for treatment of recurrent prostate cancer (Simons et al., 2006; Small et al., 2007), breast cancer (Emens et al., 2009) and pancreatic cancer (Lutz et al., 2011). Although the phase II results of allogeneic GVAX prostate cancer vaccine trials were encouraging, phase III clinical trials that were designed to examine GVAX or GVAX in combination with chemotherapies for the treatment of metastatic castrate resistant prostate cancer (CRPC) failed to achieve a survival benefit and were terminated (Antonarakis and Drake, 2010; Lassi and Dawson, 2010). Despite these disappointing results, other combination strategies involving GVAX prostate cancer vaccine and anti-CTLA-4 antibodies (i.e., ipilimumab), an immunomodulating agent recently approved by the FDA for treatment of metastatic melanoma, are still being pursued (van den Eertwegh et al., 2012; Wang et al., 2011a).

Initial autologous tumor cell vaccines for non-small cell lung cancer (NSCLC) encountered manufacturing failures due to the availability of tumor specimens, although the results from pilot studies were positive (Hege and Carbone, 2003; Nemunaitis et al., 2004; Salgia et al., 2003). An allogeneic tumor cell vaccine (belagenpumatucel-L) consisting of four NSCLC lines engineered to secret antisense oligonucleotide to immunosuppressive cytokine TGF- $\beta 2$ provides a promising strategy for the treatment of NSCLC. A dose-related survival difference was shown in a randomized phase II trial, in which stage II to IV NSCLC patients received intradermal injections of three dose levels of belagenpumatucel-L on a monthly or every-other-month schedule to a maximum of 16 injections (Nemunaitis et al., 2006; Nemunaitis et al., 2009). The ongoing phase III investigation (STOP trial) involves the use of belagenpumatucel-L as a maintenance therapy in patients with unresectable stage III/IV NSCLC who have responded to or have stable disease after first-line platinum-based chemotherapy. The objective is to compare the overall survival of subjects treated with belagenpumatucel-L versus those treated with placebo. The study commenced in July 2008 and is expected to enroll 506 patients by October 2012 (Kelly and Giaccone, 2011).

\section{DC vaccines}

\section{A. The biology of DCs}

DCs are the most potent professional antigen-presenting cells (APCs) (Banchereau and Steinman, 1998). They act as sentinels at peripheral tissues where they uptake, process and present pathogen- or host-derived antigenic peptides to naïve $\mathrm{T}$ lymphocytes at the lymphoid organs in the context of major histocompatibility (MHC) molecules (Banchereau et al., 2000; Timmerman and Levy, 1999). The significance of DCs in bridging innate and adaptive immunity is well established. Indeed, many cancer immunotherapeutic strategies target DCs directly or indirectly for the induction of antigen-specific immune responses. Earlier studies showed that different DC subsets direct development of distinct T cell populations and regulate different classes of immune responses in vivo (Maldonado-Lopez et al., 1999; Pulendran et al., 1999). An animal study showed that $\mathrm{CD}^{+} \mathrm{CD} 205^{+} \mathrm{DCs}$ present antigens through both MHC class I and MHC class II molecules, whereas CD8-33D1+ DCs utilize the MHC class II presentation pathway (Dudziak et al., 2007). In addition, targeting antigens to DCs does not always result in immune activation, because engagement of certain receptor on DCs may induce immune suppression (Li et al., 2012). It appears that DC maturation signals are critical for avoiding the induction of $\mathrm{T}$ cell tolerance 
or augmentation of effective antitumor immunity (Bonifaz et al., 2004; Hawiger et al., 2001; Idoyaga et al., 2008; Wang et al., 2012; Wei et al., 2009). Extensive studies on the biology of DCs demonstrate that three interactive signals are generally required for functional activation of DCs and subsequent innate and adaptive immunity against cancers, including adequate loading of MHC-peptide complexes to DCs for T cells priming, upregulation of co-stimulatory molecules such as CD40, CD80, and CD86, and production of cytokines capable of polarizing a Th1/Tc1 immune responses (Frankenberger and Schendel, 2012).

\section{B. Ex vivo generated DCs as cancer vaccines}

The pioneering work of Inaba, Steinman, and colleagues on culturing mouse DCs ex vivo from bone marrow precursors provided the basis of development of DC vaccines a decade ago (Inaba et al., 1992). In a similar manner, human DCs can be generated in culture from $\mathrm{CD}^{+} 4^{+}$hematopoietic progenitors or from peripheral blood-derived monocytes (Banchereau and Palucka, 2005). Preparation of DC vaccines can be achieved by loading tumorassociated antigens to patients' autologous DCs that are simultaneously treated with adjuvants. These antigen-loaded, ex vivo matured DCs are administrated back into patients to induce anti-tumor immunity. Antigens utilized for this purpose include tumor-derived proteins or peptides (Banchereau et al., 2001; Murphy et al., 1996; Schuler-Thurner et al., 2002), whole tumor cells (Berard et al., 2000; Geiger et al., 2001; Palucka et al., 2006; Salcedo et al., 2006) DNA/RNA/virus (Nair et al., 2002; Steele et al., 2011; Su et al., 2005), or fusion of tumor cells and DCs (Rosenblatt et al., 2011).

One of the first trials testing the immunogenicity of DCs was conducted in metastatic prostate cancer, in which patients received autologous DCs pulsed with HLA-A0201restricted peptides derived from prostate-specific membrane antigen (PSMA). Antigenspecific cellular responses and reduced PSA levels were observed in some patients supporting the potential use of this vaccine therapy (Murphy et al., 1996). DC vaccines have been tested in clinical trials for the treatment of prostate cancer (Kantoff et al., 2010a; Small et al., 2000; Small et al., 2006), melanoma (Lesterhuis et al., 2011; Nestle et al., 1998; Palucka et al., 2006; Romano et al., 2011; Thurner et al., 1999), renal cell carcinoma (Holtl et al., 1999), and glioma (Okada et al., 2011; Yu et al., 2001). However, this autologous vaccine regimen consists of leukaphereses to isolate peripheral blood mononuclear cells (PBMCs) from the patient and cell culture processing, which thus limits the number of vaccinations.

The Sipuleucel-T (Provenge ${ }^{\mathrm{TM}}$ ) was approved by the US FDA in 2010 for the treatment of asymptomatic metastatic castrate-resistant prostate cancer (mCRPC) (Longo, 2010). This autologous vaccine mainly consists of APCs from PBMCs that have been incubated with PA2024 that contains prostatic acid phosphatase (PAP, a prostate antigen) fused to GMCSF. Although no difference in time to progression was observed, a survival advantage was achieved, with a statistically meaningful 4.1-month improvement in median survival in the active arm with respect to the placebo arm (25.8 vs. 21.7 months). In view of its favorable toxicity profile and manageable route of administration, the success of Sipuleucel-T as the first therapeutic cancer vaccine opens exciting new paradigms for prostate cancer and other cancers.

\section{Modification of DCs to improve vaccine potency}

Despite the clinical success of APC-based prostate cancer vaccine, the modest antitumor efficacy of Sipuleucel-T emphasizes the need for improvement and optimization of this approach. Considering that $\mathrm{T}$ cell activation is finely controlled by co-stimulatory molecules expressed on DCs, modification of the expression levels of activating or inhibitory molecules could enhance the DC vaccine potency. CD40 stimulation on DCs provided by 
activated $\mathrm{CD} 4^{+} \mathrm{T}$ cells is required for $\mathrm{DC}$ licensing and cross-priming of $\mathrm{CD} 8^{+} \mathrm{T}$ cell responses (Quezada et al., 2004). CD40L overexpression in mouse DCs via virus transduction (Feder-Mengus et al., 2005; Kikuchi et al., 2000; Koya et al., 2003) or mRNA electroporation (Tcherepanova et al., 2008) led to elevated expression of B-7 molecules and enhanced production of IL-12p70, both of which are crucial for Th1-based antitumor immunity. Similarly, CD40L-expressing human DCs also resulted in increased activation of $\mathrm{T}$ cell reactivity with the poorly immunogenic tumor antigens, such as glycoprotein 100 (gp100) and Melan A (Bonehill et al., 2009; Knippertz et al., 2009). Modulation of other costimulatory molecules, such as CD70, GITRL, 4-1BBL (CD137L) and OX40L (Bonehill et al., 2008; Dannull et al., 2005; Grunebach et al., 2005; Tuyaerts et al., 2007), or proinflammatory factors, such as IL-12p70, IL-2, IL-18, CCR7 and CXCL10 also enhances DC functions by promoting its maturation/activation, migration and its capacity to stimulate antigen-specific Th1 and CTL responses (Iinuma et al., 2006; Kang et al., 2009; Minkis et al., 2008; Ogawa et al., 2004; Okada et al., 2005).

While activating molecules expressed on DCs are involved in a pro-inflammatory or antitumor $\mathrm{T}$ cell response, certain suppressive molecules contribute to $\mathrm{T}$ tolerance or suppression. The ubiquitin-editing enzyme A20 negatively regulates both TLR and TNF receptor signaling-induced maturation of DCs and subsequent activation of $\mathrm{CD} 4^{+} \mathrm{T}$ cells and CTLs in mouse models (Song et al., 2008). A20 silencing in human DCs also facilitates the development of IFN- $\gamma$ producing Th1 cells and antigen specific $\mathrm{CD}^{+} \mathrm{T}$ cells (Breckpot et al., 2009). Suppressor of cytokine signaling 1 (SOCS1), an immunosuppressive molecule induced by cytokines, such as IFN- $\gamma$, IL-12, IL-2, IL-7 and GM-CSF, has also been shown to inhibit DC functions through signal transducer and activator of transcription (STAT) signaling and impede antitumor immunity (Palmer and Restifo, 2009; Shen et al., 2004). Recently, our studies revealed that scavenger receptor SRA/CD204 represents a newly

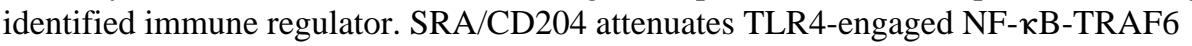
signaling pathways in DCs (Yu et al., 2011) and downregulates the immunogenicity of DCs and CTL-mediated antitumor immunity against several mouse tumors (Wang et al., 2007b; Yi et al., 2009; Yi et al., 2012). The absence or genetic silencing of SRA/CD204 profoundly enhances the immunostimulating, antigen-presenting functions of DCs and consequent antitumor immune responses involving IFN- $\gamma$ and CTLs (Guo et al., 2012a; Guo et al., 2012b; Yi et al., 2011). These findings support the concept of targeting SRA/CD204 as a strategy to optimize the potency of current DC vaccines that may be used alone or in combination with conventional therapies, such as radiotherapy.

\section{Protein/peptide-based cancer vaccines}

\section{A. Tumor-associated antigens as therapeutic targets}

The availability of patient's samples or specimens and the complex procedure of preparing individualized vaccines greatly limit the broad use of autologous cancer vaccines, including whole tumor cells or DCs. Recombinant vaccines, which are based on peptides from defined tumor-associated antigens (TAAs), and usually administered together with an adjuvant or an immune modulator, clearly have advantages. MAGE-1 is the first gene that was reported to encode a human tumor antigen recognized by T cells (van der Bruggen et al., 1991). The identification of TAAs has provided opportunities for design of targeted therapeutic vaccines, and these antigens may be classified into several major categories. Cancer-testis antigens, such as MAGE, BAGE, NY-ESO-1 and SSX-2, are encoded by genes that are normally silenced in adult tissues but transcriptionally reactivated in tumor cells (De Smet et al., 1994; Gnjatic et al., 2010; Hofmann et al., 2008; Karbach et al., 2011). Tissue differentiation antigens are those of normal tissue origin and shared by both normal tissue and tumors, such as melanoma (gp100, Melan-A/Mart-1 and tyrosinase) (Bakker et al., 1994; Kawakami et al., 1994; Parkhurst et al., 1998), prostate cancer (PSA, PAP) (Correale 
et al., 1997; Kantoff et al., 2010a) and breast carcinomas (mammaglobin-A) (Jaramillo et al., 2002). Similar to these differentiation-associated antigens, several other tumor antigens, such as CEA (Tsang et al., 1995), MUC-1(Finn et al., 2011; Kufe, 2009), HER2/Neu (Disis et al., 2009), tumor suppressor genes (p53) (Azuma et al., 2003), hTERT (Vonderheide et al., 1999) and certain anti-apoptotic proteins (i.e. livin and survivin) (Schmidt et al., 2003; Schmollinger et al., 2003) are also highly elevated in tumor tissues compared to normal counterparts. Unique tumor-specific antigens are often referred to mutated oncogenes (ras, B-raf) (Brichard and Lejeune, 2008; Parmiani et al., 2007). Targeting these tumor-specific antigens involved in driving the neoplastic process has the advantage of resistance to immunoselection with potential to be more effective. Clinical trials are underway to test vaccines that target relatively few $R A S$ mutations found in colorectal and pancreatic cancers. However, the tremendous effort required for the identification of such candidate mutations may hamper their broad clinical use (Fox et al., 2009). It is also difficult to target a wide array of frame shift mutations and unique mutations that occur in individual tumors. Other antigens for potential vaccine targets include molecules (SOX-2, OCT-4) that are associated with cancer "stem cells" (Dhodapkar et al., 2010; Dhodapkar and Dhodapkar, 2011; Spisek et al., 2007) and/or the epithelial-mesenchymal transition (EMT) process (Polyak and Weinberg, 2009).

Protein/peptide-based vaccines are more cost effective than autologous or individualized vaccines. However, they also have a potential drawback because they target only one epitope or a few epitopes of the TAA. It is generally believed that induction of both antigenspecific CTLs and antigen-specific CD4 ${ }^{+}$helper $\mathrm{T}$ cells is necessary for a cancer vaccine to be optimally efficacious. Some polypeptide vaccines (e.g., Stimuvax) potentially contain both CD4 and CD8 epitopes. Other approaches to enhance immunogenicity of a self-antigen are to alter the peptide sequence of TAAs to introduce enhancer agonist epitopes, which increase peptide binding to the MHC molecule or the T-cell receptor, resulting in higher levels of T-cell responses and/or higher avidity T cells (Dzutsev et al., 2007; Hodge et al., 2005; Hou et al., 2008; Jordan et al., 2010; Rosenberg et al., 1998).

Most peptide-based vaccines in clinical trials target cancer-testis antigens, differentiationassociated antigens, or certain oncofetal antigens (CEA, MUC-1). Although these vaccines were able to induce antigen-specific $\mathrm{T}$ cell responses, clinical outcomes have been disappointing (Buonaguro et al., 2011). In the Phase III study that led to the approval of ipilimumab (Hodi et al., 2010), no difference in overall survival was observed in patients with unresectable stage III or IV melanoma between the ipilimumab group and ipilimumab plus gp100 group. However, the encouraging results came from recent randomized Phase III trial involving patients with stage IV or locally advanced stage III cutaneous melanoma (Schwartzentruber et al., 2011). The group treated with the gp100 (210M) peptide in Montanide ISA-51 adjuvant plus IL-2 demonstrated a statistically significant improvement in overall clinical response ( $16 \%$ vs. $6 \%, P=0.03)$ as well as longer progression-free survival ( 2.2 months vs. 1.6 months, $P=0.008)$ compared with the IL-2 group. The median overall survival was also longer in the gp100 peptide vaccination plus IL-2 group than in the IL-2 group (OS $=17.8$ vs. 11.1 months; $P=0.06$ ) (Schwartzentruber et al., 2011). Indeed, this was the first phase III trial to demonstrate a clinical benefit for a peptide vaccine in melanoma. The unique findings in this trial were not observed in three previous independent phase II clinical trials (Sosman et al., 2008).

\section{B. Immunostimulatory adjuvants for protein/peptide-based vaccines}

Given that TAAs are poorly immunogenic in nature, an immunostimulatory adjuvant is essential for generation of an effective immune response. Aluminum salts (alum) have been used as adjuvants with great success for almost a century and have been particularly effective at promoting protective humoral immunity. However, alum is not optimally 
effective for diseases where cell-mediated immunity is required for protection. The recognition over the past two decades that activation of innate immunity is required to drive adaptive immune responses has radically altered theories as to how adjuvants promote adaptive immunity. In particular, the pioneering work of Charles Janeway demonstrated that adaptive immune responses are preceded by, and dependent on, innate immunity receptors triggered by microbial components (Janeway, 1992). Recognition of conserved moieties associated with pathogen or pathogen-associated molecular patterns (PAMPs) via pattern recognition receptors, e.g., toll-like receptors (TLRs), engages coordinated innate and adaptive immunity against microbial pathogen or infected cells (Kawai and Akira, 2011). TLR-mediated activation of antigen-presenting cells, e.g., DCs, is a crucial step in this process. Indeed, many established and experimental vaccines incorporate PAMPs, not only to protect against infectious diseases, but also as part of therapeutic immunizations against cancer (Wille-Reece et al., 2006). The use of these molecularly and functionally defined molecules as adjuvants greatly facilitates the rational design of vaccines.

Supporting this view, long-used BCG for the treatment of bladder carcinoma has been relatively effective and shown to activate TLR2 and TLR4 (Heldwein et al., 2003; Uehori et al., 2003). LPS, a natural ligand of TLR4, was reported to possess anticancer properties as early as the 1960s (Mizuno et al., 1968; Prigal, 1961). Monophosphoryl lipid A (MPL) is a chemically modified derivative of $S$. minnesota endotoxin that exhibits greatly reduced toxicity, but maintains most of the immunostimulatory properties of LPS (Mata-Haro et al., 2007). A plethora of studies have shown that MPL potently boosts a patient's immune response against viral and tumor-associated antigens (Schwarz, 2009). FDA approved the Cervarix vaccine formulated with MPL and aluminum salt as a prophylactic vaccine against human papillomavirus (Schiffman and Wacholder, 2012). Imiquimod (a TLR7 agonist) was approved by FDA in 2004 for use in humans against actinic keratosis and superficial basal cell carcinoma (Hoffman et al., 2005). These TLR agonists have strong potential in promoting the immunogenicity of weakly immunogenic TAAs. Indeed, several peptide/ protein-based cancer vaccines combined with TLR agonists are being tested in clinical trials; these include Ampligen targeting TLR3 (NCT01355393), Histonol targeting TLR3 (NCT00773097, NCT01585350, NCT01437605), MELITAC 12.1 targeting TLR4 (NCT01585350) and Resiquimod targeting TLR9 (NCT00960752). The family of PRRs has greatly expanded in recent years, so there is tremendous effort being expended to investigate the role of innate immune pathways in defining the mechanisms of adjuvant action as well as roles of other PRRs (e.g., NLR, RLR) in adjuvant activity of therapeutic cancer vaccines.

In addition to sensing pathogen-associated signals, PRRs also recognize endogenous 'alarmins', such as stress/heat shock proteins (HSPs) and HMGB-1(Bianchi, 2007; Lotze et al., 2007; Todryk et al., 2000). As intrinsic and highly conserved protein components of the cell, these damage-associated molecular patterns (DAMPs) also communicate the nature and magnitude of cellular injury to the host immune system. Although HSPs are known to act as molecular chaperones that participate in intracellular protein quality control (Calderwood et al., 2009; Lindquist and Craig, 1988; Mayer and Bukau, 2005), studies for the last two decades have established the concept that certain HSPs are capable of integrating both innate and adaptive immune responses, and can be utilized as immunostimulatory agents for cancer immunotherapy (Calderwood et al., 2005; Murshid et al., 2008; Srivastava, 2002a, b; Wang et al., 2006b).

Based on the early observations by Srivastava and his colleagues that HSPs isolated from cancer cells were able to induce tumor immunity (Srivastava et al., 1986; Udono et al., 1994), it was proposed that the immmunogenecity of HSPs was primarily attributed to their ability to bind antigenic peptides and transport these peptides to APCs for T cell priming (Srivastava, 2002a; Srivastava, 2005). This is consistent with the well-recognized capacity 
of chaperones to bind polypeptide chains in response to physiological stress (Welch, 1993). To date, antitumor immunity elicited by HSPs, including the cytosolic heat shock proteins Hsp70, Hsp90, Hsp110, or the ER resident Grp94/gp96, Grp170 and calreticulin, has been shown against a variety of tumors of different histologic origins such as fibrosarcomas, lung carcinomas, melanomas, colon cancers, B cell lymphoma and prostate cancer (Graner et al., 2000; Janetzki et al., 2000; Srivastava et al., 1986; Tamura et al., 1997; Vanaja et al., 2000; Wang et al., 2001; Yedavelli et al., 1999). Interestingly, HSPs (e.g., Hsp70) prepared from DC-tumor fusion cells were shown to stimulate an enhanced $\mathrm{T}$ cell response and antitumor immunity compared to tumor-derived HSPs (Enomoto et al., 2006; Gong et al., 2010). Purification of chaperones from a cancer is believed to co-purify an antigenic peptide 'fingerprint' of the cell of origin. Thus, vaccination with chaperone-peptide complexes derived from a tumor circumvents the need to identify CTL epitopes from individual cancers. This unique advantage extends the use of chaperone-based immunotherapy to cancers where specific tumor antigens have not yet been characterized.

The first autologous HSP vaccine, Oncophage (also known as HSP-peptide complex 96, HSPPC-96, Vitespen), has been examined in clinical trials of various types of malignancies, including metastatic colorectal carcinoma (Mazzaferro et al., 2003; Rivoltini et al., 2003), metastatic melanoma (Pilla et al., 2006; Testori et al., 2008), non-Hodgkin Lymphoma (Younes, 2003), RCC (Jonasch et al., 2008; Wood et al., 2008). Despite the positive results from early phase trials, the phase III trial conducted in Stage IV melanoma patients failed to demonstrate survival benefits (Testori et al., 2008). However, introspective analysis revealed overall survival benefit within the early stage IV melanoma patients (M1a, distant skin, subcutaneous or nodal metastasis; M1b, lung metastasis) (Testori et al., 2008). Similarly, no difference in recurrence-free survival between vaccination group and observation (control) group was observed in a separate phase III trial of RCC; although stage I and II patients seemed to benefit from vaccination (Wood et al., 2008). Further analysis of the data showed that patients with Stage I/II and T1/2/3a RCC had a recurrence-free survival of about $45 \%$ compared with the control group (Yang, 2008). As a result, Gp96 based vaccine (Oncophage/Vitespen) was approved in 2008 by the Russian Ministry of Health for adjuvant treatment of RCC (Carlson, 2008).

To overcome technical difficulties (tumor specimen requirement, time-consuming preparation, etc.) associated with the conventional autologous HSP vaccine approaches, we have developed a chaperoning technology to formulate recombinant HSP vaccines. This platform takes advantage of exceptional protein-holding capability of large HSPs (Hsp110, Grp170) (Easton et al., 2000; Oh et al., 1997; Park et al., 2003; Subjeck and Shyy, 1986), and generates chaperone complexes of the large HSP and clinically relevant tumor antigens (e.g., gp100, HER-2/Neu) in vitro (Manjili et al., 2002; Manjili et al., 2003; Park et al., 2006; Wang et al., 2007a; Wang et al., 2006a; Wang et al., 2003; Wang et al., 2010). The whole protein antigen employed in this approach contains a large reservoir of potential peptides that allow the individual's own MHC alleles to select the appropriate epitope for presentation, and increases the chance of polyepitope directed $\mathrm{T}$ and $\mathrm{B}$ cell responses. This synthetic approach can serve as a model to develop many different antigen targets, either alone or in combination vaccines (Wang et al., 2010). The promising preclinical results have led to a phase I clinical trial of recombinant chaperone vaccine targeting melanoma that is to be launched soon.

The immunological function of chaperones that has received the most attention thus far is the ability to shuttle peptides into the endogenous presentation pathway of professional APCs. Several receptors e.g., CD91, LOX1, SRA and SREC have been identified to be involved in the HSP-facilitated cross-priming event (Basu et al., 2001; Berwin et al., 2004; Berwin et al., 2003; Binder et al., 2000; Delneste et al., 2002; Facciponte et al., 2007; Gong 
et al., 2009; Murshid et al., 2010; Theriault et al., 2006). Intriguingly, our recent work revealed that SRA absence markedly improved the therapeutic efficacy of the Hsp110/ Grp170-gp100 vaccines in mice established with B16 melanoma (Qian et al., 2011; Wang et al., 2007b), suggesting the complex network of HSP-binding receptors and their potential distinct effects on HSP vaccine-induced immune responses.

\section{Genetic vaccines}

Another strategy to deliver antigen or antigen fragments in vivo is to utilize viral or plasmid DNA vectors carrying the expression cassettes. Upon administration, they transfect somatic cells (myocytes, keratinocytes) or DCs that infiltrate muscle or skin as a part of the inflammatory response to vaccination, resulting in a subsequent cross-priming or direct antigen presentation. One major advantage of genetic vaccines is the easy delivery of multiple antigens in one immunization and activation of various arms of immunity (Aurisicchio and Ciliberto, 2012).

\section{A. DNA vaccines}

DNA vaccines are bacterial plasmids that are constructed to function as shuttle system to deliver and express tumor antigen (full-length, short peptides) for generating targeted cellular and humoral immunity (Liu, 2011). The transgene is usually driven by the cytomegalovirus immediate early promoter and its adjacent intron A sequence to ensure transcription efficiency. Elevated expression of encoded antigen can be achieved by optimization of codon-usage, such as substitution of codons for rare tRNA (Stratford et al., 2000). The backbone of bacterial DNA itself acts as PAMPs to stimulate the activation of immune cells through TLRs or other innate pattern recognition molecules (Barber, 2011; Beutler et al., 2006; Spies et al., 2003).

The ability to incorporate multiple genes into the vector creates opportunities to modulate intracellular routing and modification of antigens as well as subsequent immune outcome. Addition of a leader sequence targeting antigens to the endoplasmic reticulum (ER) induced a humoral response (Walter and Johnson, 1994), and also facilitated generation of CD8 ${ }^{+} \mathrm{T}$ cell responses, probably due to retrograde transfer of antigen from the ER to cytosol and direct delivery of DNA to APC at the immunization site (Rice et al., 2008). Fusing the single chain $\mathrm{Fv}$ of idiotypic immunoglobulin to fragment $\mathrm{C}$ derived from tetanus toxin in DNA vaccines results in the activation of fragment $\mathrm{C}$-specific $\mathrm{CD} 4^{+} \mathrm{T}$ helper cells, which facilitate anti-Id B cells to produce high levels of anti-Id antibodies for immune protection against lymphoma (King et al., 1998; Spellerberg et al., 1997).

In addition, DNA vaccines can be rationally combined with other immunostimulatory agents, such as TLR agonists, to optimize antibody responses. DNA cancer vaccine targeting HER-2/Neu or CEA, when used in conjunction with a novel TLR9 agonist IMO (Aurisicchio et al., 2009), or a TLR7 agonist SM360320 (Dharmapuri et al., 2009), resulted in greater antibody titers and antibody-dependent cellular cytotoxicity activity, which led to improved control of HER2-positive mammary carcinoma or CEA-positive colon carcinoma in murine models. In a therapeutic setting, active immunization with HER-2/Neu DNA vaccine synergized with anti-HER-2/Neu monoclonal antibodies for enhanced inhibition of established mouse breast tumors (Orlandi et al., 2011).

Achieving an effective and durable CTL response remains the ultimate goal of cancer vaccines. Generation of $\mathrm{CD}^{+}{ }^{+} \mathrm{T}$ cell helps via a class II MHC-dependent pathway is important for amplification of $\mathrm{CD}^{+} \mathrm{T}$ cell responses and maintenance of memory during DNA vaccination (Maecker et al., 1998). Given poor immunogenicity of self TAAs , fusion of the TAAs to non-self antigens or molecules, such as virus $\times$ coat protein (Savelyeva et al., 
2001), GFP (Wolkers et al., 2002), a modified fragment C of tetanus toxin (Rice et al., 2002; Rice et al., 2006; Rice et al., 2001) can provide T helper signals to CTLs, resulting in enhanced cross-presentation of TAAs and antitumor immunity against several murine tumors. DNA vaccines that were designed to target tumor antigens to costimulatory B7 molecules on APCs by fusing the extracellular domain of CTLA-4 to HER-2/Neu induced protective humoral and cellular immune responses, which delayed onset of HER-2/Neudriven mammary carcinoma (Sloots et al., 2008).

DNA vaccines have also been tested for immune targeting of stable, proliferating endothelial cells in the tumor vasculature. A DNA vaccine with the expression cassette for vascularendothelial growth factor receptor 2 (FLK-1) promoted CTL-mediated killing of endothelial cells, resulting in potent therapeutic efficacy against several murine tumors (melanoma, colon carcinoma and lung carcinoma) and reducing the dissemination of pulmonary metastases (Niethammer et al., 2002). Oral administration of a xenogenic DNA vaccine encoding human tumor endothelial marker 8 (TEM8) effectively suppressed tumor angiogenesis and protected mice from subsequent challenge with a lethal dose of tumor cells (Ruan et al., 2009). Mice immunized with a DNA vaccine encoding human papilloma virus type-16 (HPV-16) E7 fused with calreticulin (CRT) developed a strong tumor-specific CD8 ${ }^{+}$ $\mathrm{T}$ cell response and also showed a dramatic reduction in microvessel density in lung tumor nodules, suggesting the enhanced antitumor effect involves dual immune-mediated attack of both cancer cells and endothelial cells (Cheng et al., 2001). Other DNA vaccine approaches targeting the angiostatin receptor angiomotin also augmented immune-mediated blockade of angiogenesis and tumor inhibition. Interestingly, the increased tumor vessel permeability following DNA vaccination further enhanced the antitumor effect of a chemotherapeutic agent, doxorubicin (Arigoni et al., 2012; Holmgren et al., 2006).

Although DNA vaccine platforms have shown promise in preclinical studies (Xiang et al., 2008), they fail to translate from mice and rats to non-human primates and humans (Liu and Ulmer, 2005; Rice et al., 2008). DNA vaccines are facing the obstacle of translation into the clinic due to efficacy rather than toxicity. However, new constructs and methods of administration may enhance their utility. In addition to subcutaneous or intradermal injection, DNA vaccines can be injected directly into the lymph nodes to increase antigen uptake by APCs and promote local inflammatory signals. This is currently being tested in Phase I/II trials for melanoma and other cancers (Ribas et al., 2011; Weber et al., 2011). Other approaches or carrier modalities, including gene gun, electroporation, ultrasound, laser, liposome, microparticles and nanoparticles, have been used to enhance antigen expression and DNA vaccine efficacy (Bins et al., 2005; Buchan et al., 2005; Dupuis et al., 2000; Greenland and Letvin, 2007).

\section{B. RNA vaccines}

Messenger RNA (mRNA) from autologous tumor tissues can also be used to induce a specific CTL response (Carralot et al., 2005; Scheel et al., 2005; Wolff et al., 1990). Administration of total RNA as a vaccine potentially generates immune responses against various tumor antigens to reduce the possibility of tumor escape. Unlike DNA vaccines, RNA vaccines are less likely to cause side effects or autoimmune diseases due to their rapid degradation and clearance. RNA vaccination is usually carried out together with other agents for stabilization or adjuvant effects, such as liposomes or protamines (Espuelas et al., 2005; Fotin-Mleczek et al., 2012; Qiu et al., 1996; Scheel et al., 2005). Chemical modification of the phosphodiester backbone (phosphorothioate RNA) can also provide a 'danger' signal for stimulating the DCs through the MyD88 pathway (Scheel et al., 2004). Other modifications of RNA vaccines by integrating an RNA replicase polyprotein derived from the Semliki forest virus to generate "self-replicating" RNA (Ying et al., 1999) or using $\beta$-globin UTR to stabilize the RNA vaccine (Carralot et al., 2004) also lead to enhanced antigen-specific 
immune responses. RNA-based cancer vaccines have only been clinically tested in phase I/II trials with patients with melanoma (Weide et al., 2008; Weide et al., 2009) or RCC (Oshiumi et al., 2003).

\section{Viral-based vaccines}

The rationale for using viruses as immunization vehicles is based on the phenomenon that viral infection often results in the presentation of MHC class I/II restricted, virus-specific peptides on infected cells. The viral vectors with low disease-causing potential and low intrinsic immunogenicity are engineered to encode TAAs or TAAs combined with immunomodulating molecules.

The first and most extensively evaluated viral-based vectors in cancer vaccine trials are from the poxviridae family, such as vaccinia, modified vaccinia strain Ankara (MVA), and the avipoxviruses (fowlpox and canarypox; ALVAC) (Marshall et al., 1999; Marshall et al., 2000; Walsh and Dolin, 2011). Poxviruses have the ability to accommodate large or several transgene inserts (Moss, 1996). Poxvirus replication and transcription are restricted to the cytoplasm, which minimizes risk to the host of insertional mutagenesis. It is believed that induction of a local inflammatory response by the host TLRs and other properties of vaccinia or MVA contribute to the enhanced immune response reactive with inserted TAAs in preclinical studies.

One promising viral cancer vaccine is PROSTVAC developed by Bavarian Nordic. This "off-the-shelf" platform consists of a replication-competent vaccinia priming vector and a replication-incompetent fowlpox-boosting vector. Each vector contains transgenes for PSA and three costimulatory molecules (CD80, CD54 and CD58) that are collectively designated TRICOM (Hodge et al., 2005). In double-blinded, placebo-controlled phase II trial, PROSTVAC improved median overall survival relative to the control vector (25.1 vs. 16.6 months, $P=.006$ ) (Kantoff et al., 2010b). Similar improvement in the median overall survival was also observed in a second PROSTVAC single-arm phase II study (Gulley et al., 2010). The pivotal phase III trial following these encouraging data from phase II studies are ongoing (NCT01322490).

Trovax is a MVA vector-based cancer vaccine targeting renal cell carcinoma antigen 5T4. Phase III clinical trials of Trovax in metastatic renal cancer patients failed to meet the primary endpoint of overall survival (Amato et al., 2010). Another MVA vector-based vaccine TG4010 consists of expression cassettes encoding MUC1 antigen and IL-2. In a phase II trial of renal cell carcinoma, TG4010 combined with interferon-a2a and IL-2 resulted in 22.4 months mean overall survival compared with 19.3 months for all patients. MUC-1-specific $\mathrm{CD}^{+} \mathrm{T}$ cells were associated with the prolonged survival (Oudard et al., 2011). A separate phase II trial of TG4010 combined with first-line chemotherapy (cisplatin plus gemcitabine) in advanced NSCLC demonstrated a significant 6 months increase in median survival (17.1 months in the experimental arm vs.11.3 months in the control arm). Activated NK cells were identified as predictive biomarkers for positive clinical outcome (Quoix et al., 2011). A confirmatory phase IIb/III trial of TG4010 for treatment of advanced stage (IV) NSCLC is ongoing (NCT01383148).

Recombinant adenovirus is another system that can be used as carriers for genetic vaccination. Adenoviruses are easy to engineer and propagate to high yields for clinical use. They also have the advantage of transducing both dividing and non-dividing cells for high expression of transgenes. Indeed, adenoviruses are used extensively as cancer gene therapeutic agents (Das et al., 2012; Liu et al., 2008; Raty et al., 2008). Although clinical evaluations of adenovirus platforms have been hindered by preexisting antiviral immunity, adenovirus vectors expressing various TAAs (PSA, HER-2/Neu) are currently being tested 
for their immunological and clinical efficacy (NCT00583024, NCT00197522). Newer less immunogenic variants of adenoviruses and local delivery of adenovirus-based vaccines may circumvent this issue.

Herpes simplex virus type 1 (HSV-1) is an enveloped dsDNA virus with the ability to infect a wide variety of cell types, and to incorporate single or multiple transgenes. An oncolytic HSV-1 encoding granulocyte macrophage colony-stimulating factor (GM-CSF; Oncovex ${ }^{\mathrm{GM}-\mathrm{CSF}}$ ) for direct injection into accessible melanoma lesions resulted in a $28 \%$ objective response rate in a Phase II clinical trial (Senzer et al., 2009). Responding patients demonstrated regression of both injected and noninjected lesions highlighting a dual mechanism of action of Oncovex GM-CSF which includes both a direct oncolytic activity in injected tumors and a secondary immune-mediated antitumor effect. The Oncovex GM-CSF Pivotal Trial in Melanoma (OPTIM), randomized Phase III clinical trial, has been initiated to evaluate Oncovex ${ }^{\mathrm{GM}-\mathrm{CSF}}$ in patients with unresectable, metastatic melanoma (Kaufman and Bines, 2010).

Like viral vectors, bacteria and yeasts have shown utility as vaccine vehicles in preclinical studies, and may also be modified for immunizing cancer patients. Attenuated recombinant Listeria monocytogenes has been shown to induce both innate and adaptive antitumor immune responses (Singh and Paterson, 2006, 2007). Saccharomyces cerevisiae is inherently nonpathogenic and can be easily engineered and propagated for preparation of a TAA-targeted vaccine (Remondo et al., 2009; Wansley et al., 2008).

\section{Cancer vaccine therapy combined with other treatment modalities}

Given the existence of such diverse vaccine platforms that potentially engage the innate and adaptive immune components, it is feasible and attractive to use combinatorial cancer vaccine therapy. In addition to cancer vaccines, a wide range of other promising immunotherapeutic modalities is being tested or approved for cancer treatment. These include adoptive cell transfer of ex vivo expanded tumor infiltrating lymphocytes (Rosenberg et al., 1994), use of therapeutic antibodies (e.g., trastuzumab) for antagonizing oncogenic pathways and triggering antibody dependent cytotoxicity and phagocytosis (Disis et al., 2009; Zhou and Levitsky, 2012), and administration of immune modulating antibodies targeting both co-inhibitory and co-stimulatory receptors on activated $\mathrm{T}$ cells or the corresponding ligands on APCs as well as tumor cells to enhance antitumor immune responses (Peggs et al., 2007; Wolchok et al., 2010). Therefore, a consensus view in cancer immunotherapy is developing that applications of rational combinations of multiple modalities targeting distinct aspects of tumor and immune pathways will achieve durable antitumor effects and more effective therapeutic outcomes.

A recent study demonstrated that recombinant CEA vaccines based on different poxviral and yeast platforms activated different T-cell repertoire and cytokine profiles, resulting in enhanced antitumor activity in mice (Boehm et al., 2010). Preclinical studies also showed that cancer DNA vaccine targeting CEA in combination with multiple co-stimulatory molecules (B7-1, ICAM-1, LFA-3 and GM-CSF) amplified T cell response and greatly enhanced antitumor responses (Grosenbach et al., 2001). Cancer vaccines combined with the administration of cytokines, such as IL-7 (Pellegrini et al., 2009), IFN-a (Pace et al., 2010; Sikora et al., 2009), can synergize to induce immune stimulation of DCs and T cells as well as antagonize Treg-mediated immune suppression, which leads to optimized and improved antitumor immune efficacy.

The recent FDA approval of anti-CTLA-4 antibodies (ipilimumab) for metastatic melanoma undoubtedly supports the rational combination of this immune checkpoint inhibitor with other vaccine therapies (Hodi et al., 2010; Lipson and Drake, 2011; Wang et al., 2011a). 
Although no significant difference in the OS was seen in the recent phase III trial between the ipilimumab alone group and the ipilimumab plus gp100 vaccine group (Hodi et al., 2010), ipilimumab has been shown in several preclinical and clinical studies to enhance the avidity of $\mathrm{T}$ cells and to enhance antitumor effects in combination with vaccines (Brahmer et al., 2010; Chakraborty et al., 2007; Hodi et al., 2003; van Elsas et al., 1999; Yuan et al., 2008). In addition, administration of ipilimumab after vaccination with GVAX generated clinically meaningful antitumor immunity in a majority of metastatic melanoma patients (Hodi et al., 2008). Clinical trials evaluating different combinations of ipilimumab with vaccines are planned or ongoing in the adjuvant and metastatic setting for treatment of different types of cancer (ClinicalTrials.gov Identifier: NCT01302496, NCT00124670, NCT00836407).

Other promising candidates for immune modulation to enhance clinical vaccine efficacy include antibodies against PD-1 or PD-1L1 (Brahmer et al., 2010; Curran et al., 2010; Sakuishi et al., 2010), lymphocyte-activation gene-3 (LAG-3), T cell immunoglobulin mucin-3 (Tim-3) (Fourcade et al., 2010; Sakuishi et al., 2010), CD40 (Advani et al., 2009; Beatty et al., 2011), and inhibitors of transforming growth factor $\beta$ (TGF- $\beta$ ) (Bogdahn et al., 2011; Bueno et al., 2008). The combination of PD-1 blockade with GM-CSF-secreting tumor cell immunotherapy leads to significantly improved antitumor responses in preclinical models (Li et al., 2009).

Emerging evidence from preclinical or clinical studies also support the idea of combining cancer vaccines with conventional therapies (radiation, chemotherapy) to achieve additive or synergistic effects, even though the dose and scheduling of the combining agent require additional studies for optimization. Certain chemotherapeutic agents (e.g., doxorubicin) can induce immunogenic cancer cell death, resulting in enhanced cross-priming of TAA-specific T cells and subsequent antitumor immunity (Apetoh et al., 2007; Ghiringhelli et al., 2009; Kepp et al., 2011; Tesniere et al., 2010; Zitvogel et al., 2010). Low doses of cyclophosphamide and doxorubicin also enhance the therapeutic efficacy of GM-CSF secreting whole tumor cell vaccines in tumor bearing mice and cancer patients, probably due to their ability to diminish the number of Tregs (Emens et al., 2009; Machiels et al., 2001). Docetaxel has been reported to increase the expression of TAAs, peptide-MHC complexes, and the death receptors expressed on tumor cells, thus sensitizing tumors to vaccine-induced T cell killing (Garnett et al., 2008). In addition, certain small molecule targeted therapeutics, such as BCL-2 inhibitor (Farsaci et al., 2010), B-raf inhibitor (Boni et al., 2010) and the tyrosine kinase inhibitor sunitinib (Farsaci et al., 2012; Finke et al., 2008; Ko et al., 2009) demonstrate the ability to enhance $\mathrm{T}$ cell functions and antitumor efficacy in preclinical studies. Recent studies also showed that the mTOR inhibitor rapamycin promotes production of IL-12 and development of memory $\mathrm{CD}^{+} \mathrm{T}$ cells, leading to enhanced vaccine potency (Araki et al., 2009; Ohtani et al., 2008; Wang et al., 2011b).

Local radiation not only debulks the tumor, but also generates an inflammatory microenvironment, thereby promoting presentation of dying tumor-released TAAs by DCs and subsequent $\mathrm{T}$ cell priming (Guo et al., 2012b; Hodge et al., 2008). In addition, radiation renders tumor cells more susceptible to attack by tumor-specific CTLs (Chakraborty et al., 2003; Garnett et al., 2004; Reits et al., 2006). Indeed, radiation therapy combined with a PSA-targeted vaccine displayed a favorable toxicity profile and generated significant $\mathrm{T}$ cell responses in prostate cancer patients (Gulley et al., 2005; Lechleider et al., 2008). Moreover, the preclinical and clinical evidence indicates potential benefits of hormonal therapy in combination with vaccine therapy (Arredouani et al., 2010; Mercader et al., 2001). Randomized clinical trials of PROSTVAC vaccine also suggest that vaccination combined with nilutamide hormone therapy potentially results in improved survival in patients with non-metastatic prostate cancer (Madan et al., 2008). 


\section{Lessons learned from cancer vaccine trials}

In contrast to other cytotoxic therapies, cancer vaccines have demonstrated minimal toxicity in all clinical trials that have been reported to date. Despite expression of many target TAAs in normal tissues, little evidence of autoimmunity has been observed, with the exception of vitiligo that is seen in patients receiving some melanoma vaccines (Banchereau et al., 2001; Luiten et al., 2005). Therapeutic cancer vaccines of different forms are being actively evaluated in the clinic. Ongoing Phase III trials are summarized in Table 1.

Clinical studies have now shown that patients who have received less prior chemotherapy are generally more responsive to vaccines (von Mehren et al., 2001). Thus, vaccine treatment of patients with a lower tumor burden may result in significantly improved outcomes (Gulley et al., 2011), highlighting the importance of selection of appropriate patient populations to be used in randomized vaccine trials. Strikingly, the mechanism of action and kinetics of clinical responses following vaccine therapy appear to differ significantly from that of chemotherapy (Stein et al., 2011). It may be explained by the time needed to establish the immune response, which is followed by continuing tumor cell destruction and cross-priming of $\mathrm{T}$ effector cells reactive with additional TAAs. Thus, antitumor activity of vaccine-induced immune activation over a long period results in a slower tumor growth rate and improved overall survival, even though patients fail to show substantial reductions in tumor burden and an improvement in relapse-free survival (Madan et al., 2010). Similar findings have been reported in the clinical trials evaluating ipilimumab treatment of metastatic melanoma, in which patients treated with ipilimumab showed a statistically significant advantage in overall survival without a statistically significant difference in time to progression (Hodi et al., 2010).

These findings indicate that traditional response criteria may not be adequate for evaluating clinical responses to vaccine therapy or immunotherapy. Classic Response Evaluation Criteria in Solid Tumors (RECIST criteria) were initially developed to monitor patients treated with cytotoxic chemotherapies (Therasse et al., 2006). Indeed, new guidelines or "immune response criteria" for the evaluation of immunotherapeutic activity in solid tumors have been developed to better classify and evaluate clinical activity (Wolchok et al., 2009).

Numerous studies have demonstrated that analysis of the immune infiltrates in cancer biopsies and "immune signature" can serve as independent prognostic predictors for survival (Ascierto et al., 2011; Ascierto et al., 2012; Camus et al., 2009; Galon et al., 2006). Future efforts should be focused on the identification and validation of diagnostic biomarkers in response to vaccine treatment. Obtaining information on the biomarkers of immune and clinical responsiveness to effective treatment will greatly facilitate the clinical development of therapeutic cancer vaccines.

\section{Tumor-induced immune suppression and tumor microenvironment}

Tumor-induced immunosuppressive mechanisms in the tumor microenvironment (TME) are one of the major reasons for the limited current success of therapeutic cancer vaccines. The original immuosurveillance concept proposed to interpret the cross-talk between the immune system and the tumor (Burnet, 1970) has been elaborated on by Schreiber et al. proposing the cancer 'immunoediting' theory (Dunn et al., 2002; Dunn et al., 2004). In this model, it is suggested that tumor cells that escape initial immunosurveillance may enter an equilibrium phase where they are kept in check by the immune system; as soon as the immune response is suppressed or epigenetic changes in the quiescent tumor cells result in antigen loss or HLA loss, tumor escape and recurrence will occur. It is also believed that tumor 'immunoediting' also occurs during vaccination therapy of established tumors and contributes to tumor progression or relapse (Schreiber et al., 2011). 
These immunosuppression mechanisms constitute the principle obstacles for the development of effective therapeutic cancer vaccines (Fig. 1). Tumor cells can change themselves by alterations in the antigen processing-presenting machinery, loss of antigen or induction of anti-apoptotic mechanisms (Dunn et al., 2002; Khong and Restifo, 2002; Racanelli et al., 2010; Respa et al., 2011; Seliger et al., 2010). The lack of T-cell costimulatory molecules on most solid tumors and chronic exposure to TAAs may enable activated T cells to become anergized during activation (Kim and Ahmed, 2010). The TME contains a range of immunosuppressive leukocyte populations, including myeloid derived suppressor cells (MDSCs), tumor-associated macrophages (TAMs) and Tregs. Analysis of PBMCs from patients with different types of cancer has also shown increased levels of MDSCs and Tregs with increased suppressive functions (Cesana et al., 2006; Vergati et al., 2011). These suppressive cells, tumor cells, and TAMs residing in the TME also release a number of immunosuppressive soluble factors, including TGF- $\beta$, IL-10, indoleaminepyrrole 2,3 dioxygenase (IDO), galectin, and vascular endothelial growth factor (VEGF), which promote and establish an immunosuppressive state at the tumor site (Vesely et al., 2011).

MDSCs are immature myeloid cells that express CD11b and Gr-1 markers in tumor-bearing mice (Peranzoni et al., 2010). These include monocytic MDSCs and polymorphonuclear MDSCs (granulocytic MDSCs). In cancer patients, MDSCs are characterized as LIN-HLA$\mathrm{DR}^{-} \mathrm{CD} 33^{+} \mathrm{CD} 11 \mathrm{~b}^{+}$cells in blood. There is a positive correlation between the frequency of MDSCs and advanced-stage tumors (Diaz-Montero et al., 2009; Kusmartsev et al., 2008; Raychaudhuri et al., 2011). MDSCs inhibit T cell activation via arginase, inducible nitric oxide synthase (iNOS), reactive oxygen species (ROS) or reactive nitrogen species (RNS) (Movahedi et al., 2008; Youn et al., 2008). Various mechanisms are involved in MDSCmediated immune suppression, which include depletion of nutrients necessary for lymphocytes (Rodriguez et al., 2004; Srivastava et al., 2010), generation of oxidative stress to induce the loss of TCR $\zeta$-chain expression on T cells (Schmielau and Finn, 2001) and disruption of IL-2 receptor signaling (Mazzoni et al., 2002), interference with lymphocyte trafficking (Hanson et al., 2009; Molon et al., 2011), or promoting activation of Tregs by CD40-CD40L ligation (Pan et al., 2010) and production of IL-10 or TGF- $\beta$ (Huang et al., 2006). Contact-dependent mechanisms of $T$ cell suppression have also been reported in a mouse tumor model (Morales et al., 2009).

Macrophages are derived from circulating monocytes and terminally differentiate in various tissues. They express various surface markers and function differently in response to the local environmental cues (Mosser and Edwards, 2008). It is well known that TAM facilitate tumor progression and is associated with poor clinical outcomes (Mantovani and Sica, 2010; Qian and Pollard, 2010). TAMs are M2-like or alternatively activated macrophages that facilitate tumor angiogenesis and promote tumor invasion or metastasis (Lin et al., 2006; Qian et al., 2009). TAMs also promote tumor growth by producing IL-10 to drive the development of IL-4-expressing Th2 cells, which provides a positive feedback for stimulating TAM expansion (DeNardo et al., 2009). CCL22 produced by TAMs recruits Tregs to suppress CTL function (Curiel et al., 2004). Expression of PD1 ligand (PD1L) on monocytes/macrophages can induce apoptosis of activated T cells (Kuang et al., 2009).

Tregs not only suppress physiological and pathological immune responses against self, nonself and quasi-self-tumor antigens, but also are able to attenuate antitumor functions of $\mathrm{CD}^{+}$helper T cells, NK cells, NKT cells and CD8 ${ }^{+} \mathrm{T}$ cells (Sakaguchi, 2004; Shevach, 2002). A large number of Tregs can be recruited into the TME of tumor bearing mice or cancer patients, due to the self antigens released by dying tumor cells and inflammatory TME (Nishikawa et al., 2005; Pardoll, 2003). An increased presence of CD4 ${ }^{+} \mathrm{CD} 25^{+} \mathrm{Foxp}^{+}$ Tregs over $\mathrm{CD}^{+} \mathrm{T}$ cells at the tumor site correlates with poor prognosis and therapeutic 
outcomes in cancer patients (Bates et al., 2006; Curiel et al., 2004; Sato et al., 2005). Although not clearly defined, expression of the inhibitory surface molecules CTLA-4 and PD-1, secretion of the immunosuppressive soluble factors TGF- $\beta$, IL-10 and IL-35 as well as certain cytolytic molecules may mediate immunosuppression by Tregs (Vignali et al., 2008).

In addition to the immunosuppressive TME, the immune counteracting mechanisms engaged during cancer vaccine responses may also compromise antitumor responses and contribute to tumor escape. Tregs can be expanded in response to viral-based vaccination or multiple cycles of GVAX vaccines (LaCelle et al., 2009; Zhou et al., 2006; Zhou and Levitsky, 2007). Anti-CTLA-4 antibodies abrogate Treg-mediated suppression by decreasing Tregs in the TME, but expanding the overall Tregs (Kavanagh et al., 2008; Quezada et al., 2006). Widely used TLR agonists as vaccine adjuvants (Caramalho et al., 2003; Conroy et al., 2008; Crellin et al., 2005) and PD-1 blockade (Currie et al., 2009) also enhance the proliferation or amplify the suppressive function of Tregs. GM-CSF-based cancer vaccines could potentially attenuate antitumor responses by expanding MDSCs in animal models of cancer (Serafini et al., 2004) and in cancer patients (Filipazzi et al., 2007; Slingluff et al., 2009). Other factors induced following vaccination include IL-6, IL-17 and IL-1 $\beta$, which drive the expansion of MDSCs due to their regulatory properties (Bunt et al., 2007; He et al., 2010; Rider et al., 2011). Therefore, innovative strategies are mandatory for overcoming these tumor-dependent and -independent immunoregulatory or immunosuppressive mechanisms or pathways to achieve beneficial clinical outcomes in cancer vaccine therapy.

\section{VIV. Concluding remarks}

Effective, safe and enduring cancer treatments constitute major challenges of medical sciences, with therapeutic cancer vaccines emerging as attractive approaches for provoking long-lasting protective antitumor immunity. Recent approval of the first therapeutic cancer vaccine will pave the way for developing innovative, next generation of vaccines with enahnced antitumor potency. Based on current data from clinical trials and the safety profiles of therapeutic vaccines, they will most probably be used in the adjuvant or neoadjuvant setting for the treatment of patients with minimal residual disease or more indolent metastatic disease, or those patients with a high risk of recurrence. Ultimate translation of cancer vaccines into clinically available medications with broad applications will require overcoming the immune tolerance/suppression pathways in the TME. A better understanding of host-tumor interactions and tumor immune escape mechanisms are required to develop effective cancer vaccines. Identification of unique tumor gene or protein products responsible for transformation of normal cells into tumor cells and promoting cancer progression will also uncover new potential targets for vaccine therapy. In addition, 'immune signatures' will have to be established and exploited to define patient populations who will most likely respond to and benefit from vaccine therapies. Strategically combining vaccine strategies with other agents or approaches that synergistically enhance antitumor immunity and/or engage complementary antitumor responses should also lead to further improved clinical outcomes.

\section{Acknowledgments}

The work was supported in part by American Cancer Society Scholarship RSG-08-187-01-LIB (X-Y. Wang), NIH CA129111 (X-Y. Wang), CA154708 (X-Y. Wang), CA097318 (P.B. Fisher), DOD Prostate Cancer Research Program W81XWH-10-PCRP-SIDA (P.B. Fisher and X-Y. Wang), and NCI Cancer Center Support Grants to Massey Cancer Center. X-Y. Wang and D. Sarkar are Harrison Scholars and P.B. Fisher holds the Thelma Newmeyer Corman Chair in Cancer Research in the VCU Massey Cancer Center. 


\section{REFERENCES}

Advani R, Forero-Torres A, Furman RR, Rosenblatt JD, Younes A, Ren H, Harrop K, Whiting N, Drachman JG. Phase I study of the humanized anti-CD40 monoclonal antibody dacetuzumab in refractory or recurrent non-Hodgkin's lymphoma. Journal of clinical oncology : official journal of the American Society of Clinical Oncology. 2009; 27:4371-4377. [PubMed: 19636010]

Amato RJ, Hawkins RE, Kaufman HL, Thompson JA, Tomczak P, Szczylik C, McDonald M, Eastty S, Shingler WH, de Belin J, Goonewardena M, Naylor S, Harrop R. Vaccination of metastatic renal cancer patients with MVA-5T4: a randomized, double-blind, placebo-controlled phase III study. Clinical cancer research : an official journal of the American Association for Cancer Research. 2010; 16:5539-5547. [PubMed: 20881001]

Antonarakis ES, Drake CG. Current status of immunological therapies for prostate cancer. Curr Opin Urol. 2010; 20:241-246. [PubMed: 20179598]

Antonia SJ, Seigne J, Diaz J, Muro-Cacho C, Extermann M, Farmelo MJ, Friberg M, Alsarraj M, Mahany JJ, Pow-Sang J, Cantor A, Janssen W. Phase I trial of a B7-1 (CD80) gene modified autologous tumor cell vaccine in combination with systemic interleukin-2 in patients with metastatic renal cell carcinoma. J Urol. 2002; 167:1995-2000. [PubMed: 11956426]

Apetoh L, Ghiringhelli F, Tesniere A, Obeid M, Ortiz C, Criollo A, Mignot G, Maiuri MC, Ullrich E, Saulnier P, Yang H, Amigorena S, Ryffel B, Barrat FJ, Saftig P, Levi F, Lidereau R, Nogues C, Mira J-P, Chompret A, Joulin V, Clavel-Chapelon F, Bourhis J, Andre F, Delaloge S, Tursz T, Kroemer G, Zitvogel L. Toll-like receptor 4-dependent contribution of the immune system to anticancer chemotherapy and radiotherapy. Nat Med. 2007; 13:1050-1059. [PubMed: 17704786]

Araki K, Turner AP, Shaffer VO, Gangappa S, Keller SA, Bachmann MF, Larsen CP, Ahmed R. mTOR regulates memory CD8 T-cell differentiation. Nature. 2009; 460:108-112. [PubMed: 19543266]

Arigoni M, Barutello G, Lanzardo S, Longo D, Aime S, Curcio C, Iezzi M, Zheng Y, Barkefors I, Holmgren L, Cavallo F. A vaccine targeting angiomotin induces an antibody response which alters tumor vessel permeability and hampers the growth of established tumors. Angiogenesis. 2012; 15:305-316. [PubMed: 22426512]

Armstrong CA, Botella R, Galloway TH, Murray N, Kramp JM, Song IS, Ansel JC. Antitumor effects of granulocyte-macrophage colony-stimulating factor production by melanoma cells. Cancer research. 1996; 56:2191-2198. [PubMed: 8616871]

Arredouani MS, Tseng-Rogenski SS, Hollenbeck BK, Escara-Wilke J, Leander KR, Defeo-Jones D, Hwang C, Sanda MG. Androgen ablation augments human HLA2.1-restricted T cell responses to PSA self-antigen in transgenic mice. The Prostate. 2010; 70:1002-1011. [PubMed: 20209643]

Asada H, Kishida T, Hirai H, Satoh E, Ohashi S, Takeuchi M, Kubo T, Kita M, Iwakura Y, Imanishi J, Mazda O. Significant antitumor effects obtained by autologous tumor cell vaccine engineered to secrete interleukin (IL)-12 and IL-18 by means of the EBV/lipoplex. Mol Ther. 2002; 5:609-616. [PubMed: 11991752]

Ascierto ML, De Giorgi V, Liu Q, Bedognetti D, Spivey TL, Murtas D, Uccellini L, Ayotte BD, Stroncek DF, Chouchane L, Manjili MH, Wang E, Marincola FM. An immunologic portrait of cancer. Journal of translational medicine. 2011; 9:146. [PubMed: 21875439]

Ascierto ML, Kmieciak M, Idowu MO, Manjili R, Zhao Y, Grimes M, Dumur C, Wang E, Ramakrishnan V, Wang XY, Bear HD, Marincola FM, Manjili MH. A signature of immune function genes associated with recurrence-free survival in breast cancer patients. Breast cancer research and treatment. 2012; 131:871-880. [PubMed: 21479927]

Aurisicchio L, Ciliberto G. Genetic cancer vaccines: current status and perspectives. Expert opinion on biological therapy. 2012; 12:1043-1058. [PubMed: 22577875]

Aurisicchio L, Peruzzi D, Conforti A, Dharmapuri S, Biondo A, Giampaoli S, Fridman A, Bagchi A, Winkelmann CT, Gibson R, Kandimalla ER, Agrawal S, Ciliberto G, La Monica N. Treatment of mammary carcinomas in HER-2 transgenic mice through combination of genetic vaccine and an agonist of Toll-like receptor 9. Clinical cancer research : an official journal of the American Association for Cancer Research. 2009; 15:1575-1584. [PubMed: 19240169] 
Azuma K, Shichijo S, Maeda Y, Nakatsura T, Nonaka Y, Fujii T, Koike K, Itoh K. Mutated p53 gene encodes a nonmutated epitope recognized by HLA-B*4601-restricted and tumor cell-reactive CTLs at tumor site. Cancer Res. 2003; 63:854-858. [PubMed: 12591737]

Baars A, van Riel JM, Cuesta MA, Jaspars EH, Pinedo HM, van den Eertwegh AJ. Metastasectomy and active specific immunotherapy for a large single melanoma metastasis. Hepatogastroenterology. 2002; 49:691-693. [PubMed: 12063971]

Bakker AB, Schreurs MW, de Boer AJ, Kawakami Y, Rosenberg SA, Adema GJ, Figdor CG. Melanocyte lineage-specific antigen gp100 is recognized by melanoma-derived tumor-infiltrating lymphocytes. J Exp Med. 1994; 179:1005-1009. [PubMed: 8113668]

Banchereau J, Briere F, Caux C, Davoust J, Lebecque S, Liu YJ, Pulendran B, Palucka K. Immunobiology of dendritic cells. Annu Rev Immunol. 2000; 18:767-811. [PubMed: 10837075]

Banchereau J, Palucka AK. Dendritic cells as therapeutic vaccines against cancer. Nature reviews. Immunology. 2005; 5:296-306. [PubMed: 15803149]

Banchereau J, Palucka AK, Dhodapkar M, Burkeholder S, Taquet N, Rolland A, Taquet S, Coquery S, Wittkowski KM, Bhardwaj N, Pineiro L, Steinman R, Fay J. Immune and clinical responses in patients with metastatic melanoma to $\mathrm{CD} 34(+)$ progenitor-derived dendritic cell vaccine. Cancer research. 2001; 61:6451-6458. [PubMed: 11522640]

Banchereau J, Steinman RM. Dendritic cells and the control of immunity. Nature. 1998; 392:245-252. [PubMed: 9521319]

Barber GN. Cytoplasmic DNA innate immune pathways. Immunol Rev. 2011; 243:99-108. [PubMed: 21884170]

Basu S, Binder RJ, Ramalingam T, Srivastava PK. CD91 is a common receptor for heat shock proteins gp96, hsp90, hsp70, and calreticulin. Immunity. 2001; 14:303-313. [PubMed: 11290339]

Bates GJ, Fox SB, Han C, Leek RD, Garcia JF, Harris AL, Banham AH. Quantification of regulatory $T$ cells enables the identification of high-risk breast cancer patients and those at risk of late relapse. Journal of clinical oncology : official journal of the American Society of Clinical Oncology. 2006; 24:5373-5380. [PubMed: 17135638]

Beatty GL, Chiorean EG, Fishman MP, Saboury B, Teitelbaum UR, Sun W, Huhn RD, Song W, Li D, Sharp LL, Torigian DA, O'Dwyer PJ, Vonderheide RH. CD40 agonists alter tumor stroma and show efficacy against pancreatic carcinoma in mice and humans. Science. 2011; 331:1612-1616. [PubMed: 21436454]

Berard F, Blanco P, Davoust J, Neidhart-Berard EM, Nouri-Shirazi M, Taquet N, Rimoldi D, Cerottini JC, Banchereau J, Palucka AK. Cross-priming of naive CD8 T cells against melanoma antigens using dendritic cells loaded with killed allogeneic melanoma cells. The Journal of experimental medicine. 2000; 192:1535-1544. [PubMed: 11104796]

Berd D, Maguire HC Jr. McCue P, Mastrangelo MJ. Treatment of metastatic melanoma with an autologous tumor-cell vaccine: clinical and immunologic results in 64 patients. Journal of clinical oncology : official journal of the American Society of Clinical Oncology. 1990; 8:1858-1867. [PubMed: 2230873]

Berger M, Kreutz FT, Horst JL, Baldi AC, Koff WJ. Phase I study with an autologous tumor cell vaccine for locally advanced or metastatic prostate cancer. J Pharm Pharm Sci. 2007; 10:144-152. [PubMed: 17706173]

Berwin B, Delneste Y, Lovingood RV, Post SR, Pizzo SV. SREC-I, a type F scavenger receptor, is an endocytic receptor for calreticulin. J Biol Chem. 2004; 279:51250-51257. [PubMed: 15371419]

Berwin B, Hart JP, Rice S, Gass C, Pizzo SV, Post SR, Nicchitta CV. Scavenger receptor-A mediates gp96/GRP94 and calreticulin internalization by antigen-presenting cells. Embo J. 2003; 22:61276136. [PubMed: 14609958]

Beutler B, Jiang Z, Georgel P, Crozat K, Croker B, Rutschmann S, Du X, Hoebe K. Genetic analysis of host resistance: Toll-like receptor signaling and immunity at large. Annual review of immunology. 2006; 24:353-389.

Bianchi ME. DAMPs, PAMPs and alarmins: all we need to know about danger. J Leukoc Biol. 2007; 81:1-5. [PubMed: 17032697]

Binder RJ, Han DK, Srivastava PK. CD91: a receptor for heat shock protein gp96. Nat Immunol. 2000; 1:151-155. [PubMed: 11248808] 
Bins AD, Jorritsma A, Wolkers MC, Hung CF, Wu TC, Schumacher TN, Haanen JB. A rapid and potent DNA vaccination strategy defined by in vivo monitoring of antigen expression. Nat Med. 2005; 11:899-904. [PubMed: 15965482]

Boehm AL, Higgins J, Franzusoff A, Schlom J, Hodge JW. Concurrent vaccination with two distinct vaccine platforms targeting the same antigen generates phenotypically and functionally distinct $\mathrm{T}$ cell populations. Cancer immunology, immunotherapy : CII. 2010; 59:397-408.

Bogdahn U, Hau P, Stockhammer G, Venkataramana NK, Mahapatra AK, Suri A, Balasubramaniam A, Nair S, Oliushine V, Parfenov V, Poverennova I, Zaaroor M, Jachimczak P, Ludwig S, Schmaus S, Heinrichs H, Schlingensiepen KH, Trabedersen Glioma Study G. Targeted therapy for high-grade glioma with the TGF-beta2 inhibitor trabedersen: results of a randomized and controlled phase IIb study. Neuro-oncology. 2011; 13:132-142. [PubMed: 20980335]

Bonehill A, Tuyaerts S, Van Nuffel AM, Heirman C, Bos TJ, Fostier K, Neyns B, Thielemans K. Enhancing the T-cell stimulatory capacity of human dendritic cells by co-electroporation with CD40L, CD70 and constitutively active TLR4 encoding mRNA. Mol Ther. 2008; 16:1170-1180. [PubMed: 18431362]

Bonehill A, Van Nuffel AM, Corthals J, Tuyaerts S, Heirman C, Francois V, Colau D, van der Bruggen P, Neyns B, Thielemans K. Single-step antigen loading and activation of dendritic cells by mRNA electroporation for the purpose of therapeutic vaccination in melanoma patients. Clinical cancer research : an official journal of the American Association for Cancer Research. 2009; 15:3366-3375. [PubMed: 19417017]

Boni A, Cogdill AP, Dang P, Udayakumar D, Njauw CN, Sloss CM, Ferrone CR, Flaherty KT, Lawrence DP, Fisher DE, Tsao H, Wargo JA. Selective BRAFV600E inhibition enhances T-cell recognition of melanoma without affecting lymphocyte function. Cancer research. 2010; 70:52135219. [PubMed: 20551059]

Bonifaz LC, Bonnyay DP, Charalambous A, Darguste DI, Fujii S, Soares H, Brimnes MK, Moltedo B, Moran TM, Steinman RM. In vivo targeting of antigens to maturing dendritic cells via the DEC-205 receptor improves T cell vaccination. The Journal of experimental medicine. 2004; 199:815-824. [PubMed: 15024047]

Brahmer JR, Drake CG, Wollner I, Powderly JD, Picus J, Sharfman WH, Stankevich E, Pons A, Salay TM, McMiller TL, Gilson MM, Wang C, Selby M, Taube JM, Anders R, Chen L, Korman AJ, Pardoll DM, Lowy I, Topalian SL. Phase I study of single-agent anti-programmed death-1 (MDX-1106) in refractory solid tumors: safety, clinical activity, pharmacodynamics, and immunologic correlates. Journal of clinical oncology : official journal of the American Society of Clinical Oncology. 2010; 28:3167-3175. [PubMed: 20516446]

Breckpot K, Aerts-Toegaert C, Heirman C, Peeters U, Beyaert R, Aerts JL, Thielemans K. Attenuated expression of A20 markedly increases the efficacy of double-stranded RNA-activated dendritic cells as an anti-cancer vaccine. J Immunol. 2009; 182:860-870. [PubMed: 19124729]

Brichard VG, Lejeune D. Cancer immunotherapy targeting tumour-specific antigens: towards a new therapy for minimal residual disease. Expert opinion on biological therapy. 2008; 8:951-968. [PubMed: 18549325]

Buchan S, Gronevik E, Mathiesen I, King CA, Stevenson FK, Rice J. Electroporation as a "prime/ boost" strategy for naked DNA vaccination against a tumor antigen. J Immunol. 2005; 174:62926298. [PubMed: 15879128]

Bueno L, de Alwis DP, Pitou C, Yingling J, Lahn M, Glatt S, Troconiz IF. Semi-mechanistic modelling of the tumour growth inhibitory effects of LY2157299, a new type I receptor TGF-beta kinase antagonist, in mice. European journal of cancer. 2008; 44:142-150. [PubMed: 18039567]

Bunt SK, Yang L, Sinha P, Clements VK, Leips J, Ostrand-Rosenberg S. Reduced inflammation in the tumor microenvironment delays the accumulation of myeloid-derived suppressor cells and limits tumor progression. Cancer Res. 2007; 67:10019-10026. [PubMed: 17942936]

Buonaguro L, Petrizzo A, Tornesello ML, Buonaguro FM. Translating tumor antigens into cancer vaccines. Clin Vaccine Immunol. 2011; 18:23-34. [PubMed: 21048000]

Burnet FM. The concept of immunological surveillance. Prog Exp Tumor Res. 1970; 13:1-27. [PubMed: 4921480] 
Butte MJ, Keir ME, Phamduy TB, Sharpe AH, Freeman GJ. Programmed death-1 ligand 1 interacts specifically with the B7-1 costimulatory molecule to inhibit T cell responses. Immunity. 2007; 27:111-122. [PubMed: 17629517]

Calderwood SK, Murshid A, Prince T. The shock of aging: molecular chaperones and the heat shock response in longevity and aging--a mini-review. Gerontology. 2009; 55:550-558. [PubMed: 19546513]

Calderwood SK, Theriault JR, Gong J. Message in a bottle: role of the 70-kDa heat shock protein family in anti-tumor immunity. Eur J Immunol. 2005; 35:2518-2527. [PubMed: 16144035]

Camus M, Tosolini M, Mlecnik B, Pages F, Kirilovsky A, Berger A, Costes A, Bindea G, Charoentong P, Bruneval P, Trajanoski Z, Fridman WH, Galon J. Coordination of intratumoral immune reaction and human colorectal cancer recurrence. Cancer research. 2009; 69:2685-2693. [PubMed: 19258510]

Caramalho I, Lopes-Carvalho T, Ostler D, Zelenay S, Haury M, Demengeot J. Regulatory T cells selectively express toll-like receptors and are activated by lipopolysaccharide. The Journal of experimental medicine. 2003; 197:403-411. [PubMed: 12591899]

Carlson B. Research, conferences, and FDA actions. Biotechnol Healthc. 2008; 5:7-16. [PubMed: 22478695]

Carralot JP, Probst J, Hoerr I, Scheel B, Teufel R, Jung G, Rammensee HG, Pascolo S. Polarization of immunity induced by direct injection of naked sequence-stabilized mRNA vaccines. Cell Mol Life Sci. 2004; 61:2418-2424. [PubMed: 15378210]

Carralot JP, Weide B, Schoor O, Probst J, Scheel B, Teufel R, Hoerr I, Garbe C, Rammensee HG, Pascolo S. Production and characterization of amplified tumor-derived cRNA libraries to be used as vaccines against metastatic melanomas. Genet Vaccines Ther. 2005; 3:6. [PubMed: 16115316]

Cesana GC, DeRaffele G, Cohen S, Moroziewicz D, Mitcham J, Stoutenburg J, Cheung K, Hesdorffer C, Kim-Schulze S, Kaufman HL. Characterization of CD4+CD25+ regulatory T cells in patients treated with high-dose interleukin-2 for metastatic melanoma or renal cell carcinoma. Journal of clinical oncology : official journal of the American Society of Clinical Oncology. 2006; 24:11691177. [PubMed: 16505437]

Chakraborty M, Abrams SI, Camphausen K, Liu K, Scott T, Coleman CN, Hodge JW. Irradiation of tumor cells up-regulates Fas and enhances CTL lytic activity and CTL adoptive immunotherapy. J Immunol. 2003; 170:6338-6347. [PubMed: 12794167]

Chakraborty M, Schlom J, Hodge JW. The combined activation of positive costimulatory signals with modulation of a negative costimulatory signal for the enhancement of vaccine-mediated T-cell responses. Cancer immunology, immunotherapy : CII. 2007; 56:1471-1484.

Cheever MA, Higano CS. PROVENGE (Sipuleucel-T) in prostate cancer: the first FDA-approved therapeutic cancer vaccine. Clinical cancer research : an official journal of the American Association for Cancer Research. 2011; 17:3520-3526. [PubMed: 21471425]

Cheng WF, Hung CF, Chai CY, Hsu KF, He L, Ling M, Wu TC. Tumor-specific immunity and antiangiogenesis generated by a DNA vaccine encoding calreticulin linked to a tumor antigen. $\mathrm{J}$ Clin Invest. 2001; 108:669-678. [PubMed: 11544272]

Conroy H, Marshall NA, Mills KH. TLR ligand suppression or enhancement of Treg cells? A doubleedged sword in immunity to tumours. Oncogene. 2008; 27:168-180. [PubMed: 18176598]

Correale P, Walmsley K, Nieroda C, Zaremba S, Zhu M, Schlom J, Tsang KY. In vitro generation of human cytotoxic $\mathrm{T}$ lymphocytes specific for peptides derived from prostate-specific antigen. J Natl Cancer Inst. 1997; 89:293-300. [PubMed: 9048833]

Crellin NK, Garcia RV, Hadisfar O, Allan SE, Steiner TS, Levings MK. Human CD4+ T cells express TLR5 and its ligand flagellin enhances the suppressive capacity and expression of FOXP3 in CD4+CD25+ T regulatory cells. Journal of immunology. 2005; 175:8051-8059.

Curiel TJ, Coukos G, Zou L, Alvarez X, Cheng P, Mottram P, Evdemon-Hogan M, Conejo-Garcia JR, Zhang L, Burow M, Zhu Y, Wei S, Kryczek I, Daniel B, Gordon A, Myers L, Lackner A, Disis ML, Knutson KL, Chen L, Zou W. Specific recruitment of regulatory T cells in ovarian carcinoma fosters immune privilege and predicts reduced survival. Nat Med. 2004; 10:942-949. [PubMed: 15322536] 
Curran MA, Allison JP. Tumor vaccines expressing flt3 ligand synergize with ctla-4 blockade to reject preimplanted tumors. Cancer Res. 2009; 69:7747-7755. [PubMed: 19738077]

Curran MA, Montalvo W, Yagita H, Allison JP. PD-1 and CTLA-4 combination blockade expands infiltrating T cells and reduces regulatory T and myeloid cells within B16 melanoma tumors. Proc Natl Acad Sci U S A. 2010; 107:4275-4280. [PubMed: 20160101]

Currie AJ, Prosser A, McDonnell A, Cleaver AL, Robinson BW, Freeman GJ, van der Most RG. Dual control of antitumor CD8 T cells through the programmed death-1/programmed death-ligand 1 pathway and immunosuppressive CD4 T cells: regulation and counterregulation. Journal of immunology. 2009; 183:7898-7908.

Dannull J, Nair S, Su Z, Boczkowski D, DeBeck C, Yang B, Gilboa E, Vieweg J. Enhancing the immunostimulatory function of dendritic cells by transfection with mRNA encoding OX40 ligand. Blood. 2005; 105:3206-3213. [PubMed: 15618466]

Das SK, Sarkar S, Dash R, Dent P, Wang XY, Sarkar D, Fisher PB. Cancer terminator viruses and approaches for enhancing therapeutic outcomes. Advances in cancer research. 2012; 115:1-38. [PubMed: 23021240]

Davis MB, Vasquez-Dunddel D, Fu J, Albesiano E, Pardoll D, Kim YJ. Intratumoral administration of TLR4 agonist absorbed into a cellular vector improves antitumor responses. Clinical cancer research : an official journal of the American Association for Cancer Research. 2011; 17:39843992. [PubMed: 21543518]

De Smet C, Lurquin C, van der Bruggen P, De Plaen E, Brasseur F, Boon T. Sequence and expression pattern of the human MAGE2 gene. Immunogenetics. 1994; 39:121-129. [PubMed: 8276455]

de Weger VA, Turksma AW, Voorham QJ, Euler Z, Bril H, van den Eertwegh AJ, Bloemena E, Pinedo HM, Vermorken JB, van Tinteren H, Meijer GA, Hooijberg E. Clinical effects of adjuvant active specific immunotherapy differ between patients with microsatellite-stable and microsatellite-instable colon cancer. Clinical cancer research : an official journal of the American Association for Cancer Research. 2012; 18:882-889. [PubMed: 22156611]

Delneste Y, Magistrelli G, Gauchat J, Haeuw J, Aubry J, Nakamura K, Kawakami-Honda N, Goetsch L, Sawamura T, Bonnefoy J, Jeannin P. Involvement of LOX-1 in dendritic cell-mediated antigen cross-presentation. Immunity. 2002; 17:353-362. [PubMed: 12354387]

DeNardo DG, Barreto JB, Andreu P, Vasquez L, Tawfik D, Kolhatkar N, Coussens LM. CD4(+) T cells regulate pulmonary metastasis of mammary carcinomas by enhancing protumor properties of macrophages. Cancer Cell. 2009; 16:91-102. [PubMed: 19647220]

Dharmapuri S, Aurisicchio L, Neuner P, Verdirame M, Ciliberto G, La Monica N. An oral TLR7 agonist is a potent adjuvant of DNA vaccination in transgenic mouse tumor models. Cancer Gene Ther. 2009; 16:462-472. [PubMed: 18989354]

Dhodapkar KM, Feldman D, Matthews P, Radfar S, Pickering R, Turkula S, Zebroski H, Dhodapkar MV. Natural immunity to pluripotency antigen OCT4 in humans. Proceedings of the National Academy of Sciences of the United States of America. 2010; 107:8718-8723. [PubMed: 20404147]

Dhodapkar MV, Dhodapkar KM. Spontaneous and therapy-induced immunity to pluripotency genes in humans: clinical implications, opportunities and challenges. Cancer immunology, immunotherapy : CII. 2011; 60:413-418.

Diaz-Montero CM, Salem ML, Nishimura MI, Garrett-Mayer E, Cole DJ, Montero AJ. Increased circulating myeloid-derived suppressor cells correlate with clinical cancer stage, metastatic tumor burden, and doxorubicin-cyclophosphamide chemotherapy. Cancer immunology, immunotherapy : CII. 2009; 58:49-59.

Disis ML, Wallace DR, Gooley TA, Dang Y, Slota M, Lu H, Coveler AL, Childs JS, Higgins DM, Fintak PA, dela Rosa C, Tietje K, Link J, Waisman J, Salazar LG. Concurrent trastuzumab and HER2/neu-specific vaccination in patients with metastatic breast cancer. Journal of clinical oncology : official journal of the American Society of Clinical Oncology. 2009; 27:4685-4692. [PubMed: 19720923]

Dong Z, Yoneda J, Kumar R, Fidler IJ. Angiostatin-mediated suppression of cancer metastases by primary neoplasms engineered to produce granulocyte/macrophage colony-stimulating factor. The Journal of experimental medicine. 1998; 188:755-763. [PubMed: 9705957] 
Dranoff G. GM-CSF-based cancer vaccines. Immunological Reviews. 2002; 188:147-154. [PubMed: 12445288]

Dranoff G, Jaffee E, Lazenby A, Golumbek P, Levitsky H, Brose K, Jackson V, Hamada H, Pardoll D, Mulligan RC. Vaccination with irradiated tumor cells engineered to secrete murine granulocytemacrophage colony-stimulating factor stimulates potent, specific, and long-lasting anti-tumor immunity. Proceedings of the National Academy of Sciences. 1993a; 90:3539-3543.

Dranoff G, Jaffee E, Lazenby A, Golumbek P, Levitsky H, Brose K, Jackson V, Hamada H, Pardoll D, Mulligan RC. Vaccination with irradiated tumor cells engineered to secrete murine granulocytemacrophage colony-stimulating factor stimulates potent, specific, and long-lasting anti-tumor immunity. Proc Natl Acad Sci U S A. 1993b; 90:3539-3543. [PubMed: 8097319]

Dranoff G, Soiffer R, Lynch T, Mihm M, Jung K, Kolesar K, Liebster L, Lam P, Duda R, Mentzer S, Singer S, Tanabe K, Johnson R, Sober A, Bhan A, Clift S, Cohen L, Parry G, Rokovich J, Richards L, Drayer J, Berns A, Mulligan RC. A phase I study of vaccination with autologous, irradiated melanoma cells engineered to secrete human granulocyte-macrophage colony stimulating factor. Hum Gene Ther. 1997; 8:111-123. [PubMed: 8990000]

Dudziak D, Kamphorst AO, Heidkamp GF, Buchholz VR, Trumpfheller C, Yamazaki S, Cheong C, Liu K, Lee HW, Park CG, Steinman RM, Nussenzweig MC. Differential antigen processing by dendritic cell subsets in vivo. Science. 2007; 315:107-111. [PubMed: 17204652]

Dunn GP, Bruce AT, Ikeda H, Old LJ, Schreiber RD. Cancer immunoediting: from immunosurveillance to tumor escape. Nat Immunol. 2002; 3:991-998. [PubMed: 12407406]

Dunn GP, Old LJ, Schreiber RD. The three Es of cancer immunoediting. Annual review of immunology. 2004; 22:329-360.

Dunussi-Joannopoulos K, Dranoff G, Weinstein HJ, Ferrara JL, Bierer BE, Croop JM. Gene immunotherapy in murine acute myeloid leukemia: granulocyte-macrophage colony-stimulating factor tumor cell vaccines elicit more potent antitumor immunity compared with B7 family and other cytokine vaccines. Blood. 1998; 91:222-230. [PubMed: 9414288]

Dupuis M, Denis-Mize K, Woo C, Goldbeck C, Selby MJ, Chen M, Otten GR, Ulmer JB, Donnelly JJ, Ott G, McDonald DM. Distribution of DNA vaccines determines their immunogenicity after intramuscular injection in mice. Journal of immunology. 2000; 165:2850-2858.

Dzutsev AH, Belyakov IM, Isakov DV, Margulies DH, Berzofsky JA. Avidity of CD8 T cells sharpens immunodominance. International immunology. 2007; 19:497-507. [PubMed: 17376783]

Easton DP, Kaneko Y, Subjeck JR. The hsp110 and Grp1 70 stress proteins: newly recognized relatives of the Hsp70s. Cell Stress Chaperones. 2000; 5:276-290. [PubMed: 11048651]

Emens LA, Asquith JM, Leatherman JM, Kobrin BJ, Petrik S, Laiko M, Levi J, Daphtary MM, Biedrzycki B, Wolff AC, Stearns V, Disis ML, Ye X, Piantadosi S, Fetting JH, Davidson NE, Jaffee EM. Timed sequential treatment with cyclophosphamide, doxorubicin, and an allogeneic granulocyte-macrophage colony-stimulating factor-secreting breast tumor vaccine: a chemotherapy dose-ranging factorial study of safety and immune activation. Journal of clinical oncology : official journal of the American Society of Clinical Oncology. 2009; 27:5911-5918. [PubMed: 19805669]

Enomoto Y, Bharti A, Khaleque AA, Song B, Liu C, Apostolopoulos V, Xing PX, Calderwood SK, Gong J. Enhanced immunogenicity of heat shock protein 70 peptide complexes from dendritic cell-tumor fusion cells. J Immunol. 2006; 177:5946-5955. [PubMed: 17056519]

Espuelas S, Roth A, Thumann C, Frisch B, Schuber F. Effect of synthetic lipopeptides formulated in liposomes on the maturation of human dendritic cells. Mol Immunol. 2005; 42:721-729. [PubMed: 15781116]

Facciponte JG, Wang XY, Subjeck JR. Hsp110 and Grp170, members of the Hsp70 superfamily, bind to scavenger receptor-A and scavenger receptor expressed by endothelial cells-I. Eur J Immunol. 2007; 37:2268-2279. [PubMed: 17615582]

Farsaci B, Higgins JP, Hodge JW. Consequence of dose scheduling of sunitinib on host immune response elements and vaccine combination therapy. International journal of cancer. Journal international du cancer. 2012; 130:1948-1959. [PubMed: 21633954] 
Farsaci B, Sabzevari H, Higgins JP, Di Bari MG, Takai S, Schlom J, Hodge JW. Effect of a small molecule BCL-2 inhibitor on immune function and use with a recombinant vaccine. International journal of cancer. Journal international du cancer. 2010; 127:1603-1613. [PubMed: 20091862]

Feder-Mengus C, Schultz-Thater E, Oertli D, Marti WR, Heberer M, Spagnoli GC, Zajac P. Nonreplicating recombinant vaccinia virus expressing CD40 ligand enhances APC capacity to stimulate specific CD4+ and CD8+ T cell responses. Hum Gene Ther. 2005; 16:348-360. [PubMed: 15812230]

Filipazzi P, Valenti R, Huber V, Pilla L, Canese P, Iero M, Castelli C, Mariani L, Parmiani G, Rivoltini L. Identification of a new subset of myeloid suppressor cells in peripheral blood of melanoma patients with modulation by a granulocyte-macrophage colony-stimulation factorbased antitumor vaccine. Journal of clinical oncology : official journal of the American Society of Clinical Oncology. 2007; 25:2546-2553. [PubMed: 17577033]

Finke JH, Rini B, Ireland J, Rayman P, Richmond A, Golshayan A, Wood L, Elson P, Garcia J, Dreicer R, Bukowski R. Sunitinib reverses type-1 immune suppression and decreases Tregulatory cells in renal cell carcinoma patients. Clinical cancer research : an official journal of the American Association for Cancer Research. 2008; 14:6674-6682. [PubMed: 18927310]

Finn OJ, Gantt KR, Lepisto AJ, Pejawar-Gaddy S, Xue J, Beatty PL. Importance of MUC1 and spontaneous mouse tumor models for understanding the immunobiology of human adenocarcinomas. Immunologic research. 2011; 50:261-268. [PubMed: 21717081]

Fishman M, Hunter TB, Soliman H, Thompson P, Dunn M, Smilee R, Farmelo MJ, Noyes DR, Mahany JJ, Lee JH, Cantor A, Messina J, Seigne J, Pow-Sang J, Janssen W, Antonia SJ. Phase II trial of B7-1 (CD-86) transduced, cultured autologous tumor cell vaccine plus subcutaneous interleukin-2 for treatment of stage IV renal cell carcinoma. J Immunother. 2008; 31:72-80. [PubMed: 18157014]

Fotin-Mleczek M, Zanzinger K, Heidenreich R, Lorenz C, Thess A, Duchardt KM, Kallen KJ. Highly potent mRNA based cancer vaccines represent an attractive platform for combination therapies supporting an improved therapeutic effect. J Gene Med. 2012; 14:428-439. [PubMed: 22262664]

Fourcade J, Sun Z, Benallaoua M, Guillaume P, Luescher IF, Sander C, Kirkwood JM, Kuchroo V, Zarour HM. Upregulation of Tim-3 and PD-1 expression is associated with tumor antigenspecific CD8+ T cell dysfunction in melanoma patients. The Journal of experimental medicine. 2010; 207:2175-2186. [PubMed: 20819923]

Fox EJ, Salk JJ, Loeb LA. Cancer genome sequencing--an interim analysis. Cancer research. 2009; 69:4948-4950. [PubMed: 19509220]

Frankenberger B, Schendel DJ. Third generation dendritic cell vaccines for tumor immunotherapy. Eur J Cell Biol. 2012; 91:53-58. [PubMed: 21439674]

Galon J, Costes A, Sanchez-Cabo F, Kirilovsky A, Mlecnik B, Lagorce-Pages C, Tosolini M, Camus M, Berger A, Wind P, Zinzindohoue F, Bruneval P, Cugnenc PH, Trajanoski Z, Fridman WH, Pages F. Type, density, and location of immune cells within human colorectal tumors predict clinical outcome. Science. 2006; 313:1960-1964. [PubMed: 17008531]

Garnett CT, Palena C, Chakraborty M, Tsang KY, Schlom J, Hodge JW. Sublethal irradiation of human tumor cells modulates phenotype resulting in enhanced killing by cytotoxic $\mathrm{T}$ lymphocytes. Cancer Res. 2004; 64:7985-7994. [PubMed: 15520206]

Garnett CT, Schlom J, Hodge JW. Combination of docetaxel and recombinant vaccine enhances T-cell responses and antitumor activity: effects of docetaxel on immune enhancement. Clinical cancer research : an official journal of the American Association for Cancer Research. 2008; 14:35363544. [PubMed: 18519787]

Geiger JD, Hutchinson RJ, Hohenkirk LF, McKenna EA, Yanik GA, Levine JE, Chang AE, Braun TM, Mule JJ. Vaccination of pediatric solid tumor patients with tumor lysate-pulsed dendritic cells can expand specific T cells and mediate tumor regression. Cancer Res. 2001; 61:85138519. [PubMed: 11731436]

Ghiringhelli F, Apetoh L, Tesniere A, Aymeric L, Ma Y, Ortiz C, Vermaelen K, Panaretakis T, Mignot G, Ullrich E, Perfettini JL, Schlemmer F, Tasdemir E, Uhl M, Genin P, Civas A, Ryffel B, Kanellopoulos J, Tschopp J, Andre F, Lidereau R, McLaughlin NM, Haynes NM, Smyth MJ, Kroemer G, Zitvogel L. Activation of the NLRP3 inflammasome in dendritic cells induces 
IL-1beta-dependent adaptive immunity against tumors. Nat Med. 2009; 15:1170-1178. [PubMed: 19767732]

Gnjatic S, Ritter E, Buchler MW, Giese NA, Brors B, Frei C, Murray A, Halama N, Zornig I, Chen YT, Andrews C, Ritter G, Old LJ, Odunsi K, Jager D. Seromic profiling of ovarian and pancreatic cancer. Proceedings of the National Academy of Sciences of the United States of America. 2010; 107:5088-5093. [PubMed: 20194765]

Gong J, Zhang Y, Durfee J, Weng D, Liu C, Koido S, Song B, Apostolopoulos V, Calderwood SK. A heat shock protein 70-based vaccine with enhanced immunogenicity for clinical use. J Immunol. 2010; 184:488-496. [PubMed: 19949080]

Gong J, Zhu B, Murshid A, Adachi H, Song B, Lee A, Liu C, Calderwood SK. T cell activation by heat shock protein 70 vaccine requires TLR signaling and scavenger receptor expressed by endothelial cells-1. J Immunol. 2009; 183:3092-3098. [PubMed: 19641135]

Graner M, Raymond A, Romney D, He L, Whitesell L, Katsanis E. Immunoprotective activities of multiple chaperone proteins isolated from murine B-cell leukemia/lymphoma. Clin Cancer Res. 2000; 6:909-915. [PubMed: 10741715]

Greenland JR, Letvin NL. Chemical adjuvants for plasmid DNA vaccines. Vaccine. 2007; 25:37313741. [PubMed: 17350735]

Grosenbach DW, Barrientos JC, Schlom J, Hodge JW. Synergy of vaccine strategies to amplify antigen-specific immune responses and antitumor effects. Cancer research. 2001; 61:4497-4505. [PubMed: 11389081]

Grunebach F, Kayser K, Weck MM, Muller MR, Appel S, Brossart P. Cotransfection of dendritic cells with RNA coding for HER-2/neu and 4-1BBL increases the induction of tumor antigen specific cytotoxic T lymphocytes. Cancer Gene Ther. 2005; 12:749-756. [PubMed: 15877082]

Gulley JL, Arlen PM, Bastian A, Morin S, Marte J, Beetham P, Tsang K-Y, Yokokawa J, Hodge JW, Menard C, Camphausen K, Coleman CN, Sullivan F, Steinberg SM, Schlom J, Dahut W. Combining a recombinant cancer vaccine with standard definitive radiotherapy in patients with localized prostate cancer. Clin Cancer Res. 2005; 11:3353-3362. [PubMed: 15867235]

Gulley JL, Arlen PM, Madan RA, Tsang KY, Pazdur MP, Skarupa L, Jones JL, Poole DJ, Higgins JP, Hodge JW, Cereda V, Vergati M, Steinberg SM, Halabi S, Jones E, Chen C, Parnes H, Wright JJ, Dahut WL, Schlom J. Immunologic and prognostic factors associated with overall survival employing a poxviral-based PSA vaccine in metastatic castrate-resistant prostate cancer. Cancer immunology, immunotherapy : CII. 2010; 59:663-674.

Gulley JL, Madan RA, Schlom J. Impact of tumour volume on the potential efficacy of therapeutic vaccines. Current oncology. 2011; 18:e150-157. [PubMed: 21655153]

Guo C, Yi H, Yu X, Hu F, Zuo D, Subjeck JR, Wang XY. Absence of scavenger receptor A promotes dendritic cell-mediated cross-presentation of cell-associated antigen and antitumor immune response. Immunol Cell Biol. 2012a; 90:101-108. [PubMed: 21383767]

Guo C, Yi H, Yu X, Zuo D, Qian J, Yang G, Foster BA, Subjeck JR, Sun X, Mikkelsen RB, Fisher PB, Wang XY. In situ vaccination with CD204 gene-silenced dendritic cell, not unmodified dendritic cell, enhances radiation therapy of prostate cancer. Mol Cancer Ther. 2012b

Hanna MG Jr. Hoover HC Jr. Vermorken JB, Harris JE, Pinedo HM. Adjuvant active specific immunotherapy of stage II and stage III colon cancer with an autologous tumor cell vaccine: first randomized phase III trials show promise. Vaccine. 2001; 19:2576-2582. [PubMed: 11257395]

Hanna MG Jr. Peters LC. Specific immunotherapy of established visceral micrometastases by BCGtumor cell vaccine alone or as an adjunct to surgery. Cancer. 1978; 42:2613-2625. [PubMed: 728864]

Hanson EM, Clements VK, Sinha P, Ilkovitch D, Ostrand-Rosenberg S. Myeloid-derived suppressor cells down-regulate L-selectin expression on CD4+ and CD8+ T cells. J Immunol. 2009; 183:937-944. [PubMed: 19553533]

Harris JE, Ryan L, Hoover HC Jr. Stuart RK, Oken MM, Benson AB 3rd, Mansour E, Haller DG, Manola J, Hanna MG Jr. Adjuvant active specific immunotherapy for stage II and III colon cancer with an autologous tumor cell vaccine: Eastern Cooperative Oncology Group Study E5283. Journal of clinical oncology : official journal of the American Society of Clinical Oncology. 2000; 18:148-157. [PubMed: 10623705] 
Hawiger D, Inaba K, Dorsett Y, Guo M, Mahnke K, Rivera M, Ravetch JV, Steinman RM, Nussenzweig MC. Dendritic cells induce peripheral T cell unresponsiveness under steady state conditions in vivo. The Journal of experimental medicine. 2001; 194:769-779. [PubMed: 11560993]

He D, Li H, Yusuf N, Elmets CA, Li J, Mountz JD, Xu H. IL-17 promotes tumor development through the induction of tumor promoting microenvironments at tumor sites and myeloid-derived suppressor cells. Journal of immunology. 2010; 184:2281-2288.

Hege KM, Carbone DP. Lung cancer vaccines and gene therapy. Lung Cancer. 2003; 41(Suppl 1):S103-113. [PubMed: 12867069]

Heicappell R, Schirrmacher V, von Hoegen P, Ahlert T, Appelhans B. Prevention of metastatic spread by postoperative immunotherapy with virally modified autologous tumor cells. I. Parameters for optimal therapeutic effects. International journal of cancer. Journal international du cancer. 1986; 37:569-577. [PubMed: 3957462]

Heldwein KA, Liang MD, Andresen TK, Thomas KE, Marty AM, Cuesta N, Vogel SN, Fenton MJ. TLR2 and TLR4 serve distinct roles in the host immune response against Mycobacterium bovis BCG. Journal of leukocyte biology. 2003; 74:277-286. [PubMed: 12885945]

Hodge JW, Chakraborty M, Kudo-Saito C, Garnett CT, Schlom J. Multiple costimulatory modalities enhance CTL avidity. Journal of immunology. 2005; 174:5994-6004.

Hodge JW, Guha C, Neefjes J, Gulley JL. Synergizing radiation therapy and immunotherapy for curing incurable cancers. Opportunities and challenges. Oncology (Williston Park). 2008; 22:1064-1070. discussion 1075, 1080-1061, 1084. [PubMed: 18777956]

Hodi FS, Butler M, Oble DA, Seiden MV, Haluska FG, Kruse A, Macrae S, Nelson M, Canning C, Lowy I, Korman A, Lautz D, Russell S, Jaklitsch MT, Ramaiya N, Chen TC, Neuberg D, Allison JP, Mihm MC, Dranoff G. Immunologic and clinical effects of antibody blockade of cytotoxic T lymphocyte-associated antigen 4 in previously vaccinated cancer patients. Proc Natl Acad Sci U S A. 2008; 105:3005-3010. [PubMed: 18287062]

Hodi FS, Mihm MC, Soiffer RJ, Haluska FG, Butler M, Seiden MV, Davis T, Henry-Spires R, MacRae S, Willman A, Padera R, Jaklitsch MT, Shankar S, Chen TC, Korman A, Allison JP, Dranoff G. Biologic activity of cytotoxic T lymphocyte-associated antigen 4 antibody blockade in previously vaccinated metastatic melanoma and ovarian carcinoma patients. Proc Natl Acad Sci U S A. 2003; 100:4712-4717. [PubMed: 12682289]

Hodi FS, O'Day SJ, McDermott DF, Weber RW, Sosman JA, Haanen JB, Gonzalez R, Robert C, Schadendorf D, Hassel JC, Akerley W, van den Eertwegh AJ, Lutzky J, Lorigan P, Vaubel JM, Linette GP, Hogg D, Ottensmeier CH, Lebbe C, Peschel C, Quirt I, Clark JI, Wolchok JD, Weber JS, Tian J, Yellin MJ, Nichol GM, Hoos A, Urba WJ. Improved survival with ipilimumab in patients with metastatic melanoma. N Engl J Med. 2010; 363:711-723. [PubMed: 20525992]

Hoffman ES, Smith RE, Renaud RC Jr. From the analyst's couch: TLR-targeted therapeutics. Nat Rev Drug Discov. 2005; 4:879-880. [PubMed: 16299917]

Hofmann O, Caballero OL, Stevenson BJ, Chen YT, Cohen T, Chua R, Maher CA, Panji S, Schaefer U, Kruger A, Lehvaslaiho M, Carninci P, Hayashizaki Y, Jongeneel CV, Simpson AJ, Old LJ, Hide W. Genome-wide analysis of cancer/testis gene expression. Proceedings of the National Academy of Sciences of the United States of America. 2008; 105:20422-20427. [PubMed: 19088187]

Holmgren L, Ambrosino E, Birot O, Tullus C, Veitonmaki N, Levchenko T, Carlson LM, Musiani P, Iezzi M, Curcio C, Forni G, Cavallo F, Kiessling R. A DNA vaccine targeting angiomotin inhibits angiogenesis and suppresses tumor growth. Proceedings of the National Academy of Sciences of the United States of America. 2006; 103:9208-9213. [PubMed: 16754857]

Holtl L, Rieser C, Papesh C, Ramoner R, Herold M, Klocker H, Radmayr C, Stenzl A, Bartsch G, Thurnher M. Cellular and humoral immune responses in patients with metastatic renal cell carcinoma after vaccination with antigen pulsed dendritic cells. J Urol. 1999; 161:777-782. [PubMed: 10022683]

Hou Y, Kavanagh B, Fong L. Distinct CD8+ T cell repertoires primed with agonist and native peptides derived from a tumor-associated antigen. Journal of immunology. 2008; 180:1526-1534.

Hsueh EC, Essner R, Foshag LJ, Ollila DW, Gammon G, O'Day SJ, Boasberg PD, Stern SL, Ye X, Morton DL. Prolonged survival after complete resection of disseminated melanoma and active 
immunotherapy with a therapeutic cancer vaccine. J Clin Oncol. 2002; 20:4549-4554. [PubMed: 12454111]

Huang B, Pan PY, Li Q, Sato AI, Levy DE, Bromberg J, Divino CM, Chen SH. Gr-1+CD115+ immature myeloid suppressor cells mediate the development of tumor-induced T regulatory cells and T-cell anergy in tumor-bearing host. Cancer Res. 2006; 66:1123-1131. [PubMed: 16424049]

Idoyaga J, Cheong C, Suda K, Suda N, Kim JY, Lee H, Park CG, Steinman RM. Cutting edge: langerin/CD207 receptor on dendritic cells mediates efficient antigen presentation on MHC I and II products in vivo. Journal of immunology. 2008; 180:3647-3650.

Iinuma H, Okinaga K, Fukushima R, Inaba T, Iwasaki K, Okinaga A, Takahashi I, Kaneko M. Superior protective and therapeutic effects of IL-12 and IL-18 gene-transduced dendritic neuroblastoma fusion cells on liver metastasis of murine neuroblastoma. Journal of immunology. 2006; 176:3461-3469.

Inaba K, Inaba M, Romani N, Aya H, Deguchi M, Ikehara S, Muramatsu S, Steinman RM. Generation of large numbers of dendritic cells from mouse bone marrow cultures supplemented with granulocyte/macrophage colony-stimulating factor. J Exp Med. 1992; 176:1693-1702. [PubMed: 1460426]

Janetzki S, Palla D, Rosenhauer V, Lochs H, Lewis JJ, Srivastava PK. Immunization of cancer patients with autologous cancer-derived heat shock protein gp96 preparations: a pilot study. Int J Cancer. 2000; 88:232-238. [PubMed: 11004674]

Janeway CA Jr. The immune system evolved to discriminate infectious nonself from noninfectious self. Immunol Today. 1992; 13:11-16. [PubMed: 1739426]

Jaramillo A, Majumder K, Manna PP, Fleming TP, Doherty G, Dipersio JF, Mohanakumar T. Identification of HLA-A3-restricted CD8+ T cell epitopes derived from mammaglobin-A, a tumor-associated antigen of human breast cancer. International journal of cancer. Journal international du cancer. 2002; 102:499-506. [PubMed: 12432553]

Jonasch E, Wood C, Tamboli P, Pagliaro LC, Tu SM, Kim J, Srivastava P, Perez C, Isakov L, Tannir N. Vaccination of metastatic renal cell carcinoma patients with autologous tumour-derived vitespen vaccine: clinical findings. Br J Cancer. 2008; 98:1336-1341. [PubMed: 18362942]

Jordan KR, McMahan RH, Kemmler CB, Kappler JW, Slansky JE. Peptide vaccines prevent tumor growth by activating T cells that respond to native tumor antigens. Proceedings of the National Academy of Sciences of the United States of America. 2010; 107:4652-4657. [PubMed: 20133772]

Kang TH, Bae HC, Kim SH, Seo SH, Son SW, Choi EY, Seong SY, Kim TW. Modification of dendritic cells with interferon-gamma-inducible protein-10 gene to enhance vaccine potency. $\mathrm{J}$ Gene Med. 2009; 11:889-898. [PubMed: 19618483]

Kantoff PW, Higano CS, Shore ND, Berger ER, Small EJ, Penson DF, Redfern CH, Ferrari AC, Dreicer R, Sims RB, Xu Y, Frohlich MW, Schellhammer PF. Sipuleucel-T immunotherapy for castration-resistant prostate cancer. The New England journal of medicine. 2010a; 363:411-422. [PubMed: 20818862]

Kantoff PW, Schuetz TJ, Blumenstein BA, Glode LM, Bilhartz DL, Wyand M, Manson K, Panicali DL, Laus R, Schlom J, Dahut WL, Arlen PM, Gulley JL, Godfrey WR. Overall survival analysis of a phase II randomized controlled trial of a Poxviral-based PSA-targeted immunotherapy in metastatic castration-resistant prostate cancer. Journal of clinical oncology : official journal of the American Society of Clinical Oncology. 2010b; 28:1099-1105. [PubMed: 20100959]

Karbach J, Neumann A, Atmaca A, Wahle C, Brand K, von Boehmer L, Knuth A, Bender A, Ritter G, Old LJ, Jager E. Efficient in vivo priming by vaccination with recombinant NY-ESO-1 protein and $\mathrm{CpG}$ in antigen naive prostate cancer patients. Clinical cancer research : an official journal of the American Association for Cancer Research. 2011; 17:861-870. [PubMed: 21163871]

Karcher J, Dyckhoff G, Beckhove P, Reisser C, Brysch M, Ziouta Y, Helmke BH, Weidauer H, Schirrmacher V, Herold-Mende C. Antitumor vaccination in patients with head and neck squamous cell carcinomas with autologous virus-modified tumor cells. Cancer research. 2004; 64:8057-8061. [PubMed: 15520216]

Kaufman HL, Bines SD. OPTIM trial: a Phase III trial of an oncolytic herpes virus encoding GM-CSF for unresectable stage III or IV melanoma. Future oncology. 2010; 6:941-949. [PubMed: 20528232] 
Kavanagh B, O'Brien S, Lee D, Hou Y, Weinberg V, Rini B, Allison JP, Small EJ, Fong L. CTLA4 blockade expands FoxP3+ regulatory and activated effector CD4+ T cells in a dose-dependent fashion. Blood. 2008; 112:1175-1183. [PubMed: 18523152]

Kawai T, Akira S. Toll-like receptors and their crosstalk with other innate receptors in infection and immunity. Immunity. 2011; 34:637-650. [PubMed: 21616434]

Kawakami Y, Eliyahu S, Sakaguchi K, Robbins PF, Rivoltini L, Yannelli JR, Appella E, Rosenberg SA. Identification of the immunodominant peptides of the MART-1 human melanoma antigen recognized by the majority of HLA-A2-restricted tumor infiltrating lymphocytes. The Journal of experimental medicine. 1994; 180:347-352. [PubMed: 7516411]

Kelly RJ, Giaccone G. Lung cancer vaccines. Cancer J. 2011; 17:302-308. [PubMed: 21952280]

Kepp O, Galluzzi L, Martins I, Schlemmer F, Adjemian S, Michaud M, Sukkurwala AQ, Menger L, Zitvogel L, Kroemer G. Molecular determinants of immunogenic cell death elicited by anticancer chemotherapy. Cancer Metastasis Rev. 2011; 30:61-69. [PubMed: 21249425]

Khong HT, Restifo NP. Natural selection of tumor variants in the generation of "tumor escape" phenotypes. Nat Immunol. 2002; 3:999-1005. [PubMed: 12407407]

Kikuchi T, Moore MA, Crystal RG. Dendritic cells modified to express CD40 ligand elicit therapeutic immunity against preexisting murine tumors. Blood. 2000; 96:91-99. [PubMed: 10891436]

Kim PS, Ahmed R. Features of responding T cells in cancer and chronic infection. Current opinion in immunology. 2010; 22:223-230. [PubMed: 20207527]

King CA, Spellerberg MB, Zhu D, Rice J, Sahota SS, Thompsett AR, Hamblin TJ, Radl J, Stevenson FK. DNA vaccines with single-chain Fv fused to fragment $\mathrm{C}$ of tetanus toxin induce protective immunity against lymphoma and myeloma. Nat Med. 1998; 4:1281-1286. [PubMed: 9809552]

Kinoshita Y, Kono T, Yasumoto R, Kishimoto T, Wang CY, Haas GP, Nishisaka N. Antitumor effect on murine renal cell carcinoma by autologous tumor vaccines genetically modified with granulocyte-macrophage colony-stimulating factor and interleukin-6 cells. J Immunother. 2001; 24:205-211.

Knippertz I, Hesse A, Schunder T, Kampgen E, Brenner MK, Schuler G, Steinkasserer A, Nettelbeck DM. Generation of human dendritic cells that simultaneously secrete IL-12 and have migratory capacity by adenoviral gene transfer of hCD40L in combination with IFN-gamma. J Immunother. 2009; 32:524-538. [PubMed: 19609245]

Ko JS, Zea AH, Rini BI, Ireland JL, Elson P, Cohen P, Golshayan A, Rayman PA, Wood L, Garcia J, Dreicer R, Bukowski R, Finke JH. Sunitinib mediates reversal of myeloid-derived suppressor cell accumulation in renal cell carcinoma patients. Clin Cancer Res. 2009; 15:2148-2157. [PubMed: 19276286]

Koya RC, Kasahara N, Favaro PM, Lau R, Ta HQ, Weber JS, Stripecke R. Potent maturation of monocyte-derived dendritic cells after CD40L lentiviral gene delivery. J Immunother. 2003; 26:451-460. [PubMed: 12973034]

Kuang DM, Zhao Q, Peng C, Xu J, Zhang JP, Wu C, Zheng L. Activated monocytes in peritumoral stroma of hepatocellular carcinoma foster immune privilege and disease progression through PDL1. The Journal of experimental medicine. 2009; 206:1327-1337. [PubMed: 19451266]

Kufe DW. Mucins in cancer: function, prognosis and therapy. Nature reviews. Cancer. 2009; 9:874885. [PubMed: 19935676]

Kusmartsev S, Su Z, Heiser A, Dannull J, Eruslanov E, Kubler H, Yancey D, Dahm P, Vieweg J. Reversal of myeloid cell-mediated immunosuppression in patients with metastatic renal cell carcinoma. Clin Cancer Res. 2008; 14:8270-8278. [PubMed: 19088044]

LaCelle MG, Jensen SM, Fox BA. Partial CD4 depletion reduces regulatory T cells induced by multiple vaccinations and restores therapeutic efficacy. Clinical cancer research : an official journal of the American Association for Cancer Research. 2009; 15:6881-6890. [PubMed: 19903784]

Lamm DL, Blumenstein BA, Crawford ED, Montie JE, Scardino P, Grossman HB, Stanisic TH, Smith JA Jr. Sullivan J, Sarosdy MF, et al. A randomized trial of intravesical doxorubicin and immunotherapy with bacille Calmette-Guerin for transitional-cell carcinoma of the bladder. $\mathrm{N}$ Engl J Med. 1991; 325:1205-1209. [PubMed: 1922207] 
Lassi K, Dawson NA. Update on castrate-resistant prostate cancer: 2010. Curr Opin Oncol. 2010; 22:263-267. [PubMed: 20177381]

Leach DR, Krummel MF, Allison JP. Enhancement of antitumor immunity by CTLA-4 blockade. Science. 1996; 271:1734-1736. [PubMed: 8596936]

Lechleider RJ, Arlen PM, Tsang KY, Steinberg SM, Yokokawa J, Cereda V, Camphausen K, Schlom J, Dahut WL, Gulley JL. Safety and immunologic response of a viral vaccine to prostate-specific antigen in combination with radiation therapy when metronomic-dose interleukin 2 is used as an adjuvant. Clin Cancer Res. 2008; 14:5284-5291. [PubMed: 18698048]

Lesterhuis WJ, de Vries IJ, Schreibelt G, Lambeck AJ, Aarntzen EH, Jacobs JF, Scharenborg NM, van de Rakt MW, de Boer AJ, Croockewit S, van Rossum MM, Mus R, Oyen WJ, Boerman OC, Lucas S, Adema GJ, Punt CJ, Figdor CG. Route of administration modulates the induction of dendritic cell vaccine-induced antigen-specific T cells in advanced melanoma patients. Clin Cancer Res. 2011; 17:5725-5735. [PubMed: 21771874]

Levitsky HI, Montgomery J, Ahmadzadeh M, Staveley-O'Carroll K, Guarnieri F, Longo DL, Kwak LW. Immunization with granulocyte-macrophage colony-stimulating factor-transduced, but not B7-1-transduced, lymphoma cells primes idiotype-specific $\mathrm{T}$ cells and generates potent systemic antitumor immunity. Journal of immunology. 1996; 156:3858-3865.

Li B, VanRoey M, Wang C, Chen TH, Korman A, Jooss K. Anti-programmed death-1 synergizes with granulocyte macrophage colony-stimulating factor--secreting tumor cell immunotherapy providing therapeutic benefit to mice with established tumors. Clinical cancer research : an official journal of the American Association for Cancer Research. 2009; 15:1623-1634. [PubMed: 19208793]

Li D, Romain G, Flamar AL, Duluc D, Dullaers M, Li XH, Zurawski S, Bosquet N, Palucka AK, Le Grand R, O'Garra A, Zurawski G, Banchereau J, Oh S. Targeting self- and foreign antigens to dendritic cells via DC-ASGPR generates IL-10-producing suppressive CD4+ T cells. The Journal of experimental medicine. 2012; 209:109-121. [PubMed: 22213806]

Lin EY, Li JF, Gnatovskiy L, Deng Y, Zhu L, Grzesik DA, Qian H, Xue XN, Pollard JW. Macrophages regulate the angiogenic switch in a mouse model of breast cancer. Cancer research. 2006; 66:11238-11246. [PubMed: 17114237]

Lindquist S, Craig EA. The heat-shock proteins. Annu Rev Genet. 1988; 22:631-677. [PubMed: 2853609]

Lipson EJ, Drake CG. Ipilimumab: an anti-CTLA-4 antibody for metastatic melanoma. Clinical cancer research : an official journal of the American Association for Cancer Research. 2011; 17:69586962. [PubMed: 21900389]

Liu MA. DNA vaccines: an historical perspective and view to the future. Immunol Rev. 2011; 239:6284. [PubMed: 21198665]

Liu MA, Ulmer JB. Human clinical trials of plasmid DNA vaccines. Adv Genet. 2005; 55:25-40. [PubMed: 16291211]

Liu TC, Hwang TH, Bell JC, Kirn DH. Translation of targeted oncolytic virotherapeutics from the lab into the clinic, and back again: a high-value iterative loop. Mol Ther. 2008; 16:1006-1008. [PubMed: 18500240]

Lollini PL, Cavallo F, Nanni P, Forni G. Vaccines for tumour prevention. Nature reviews. Cancer. 2006; 6:204-216. [PubMed: 16498443]

Longo DL. New therapies for castration-resistant prostate cancer. The New England journal of medicine. 2010; 363:479-481. [PubMed: 20818868]

Lotze MT, Zeh HJ, Rubartelli A, Sparvero LJ, Amoscato AA, Washburn NR, Devera ME, Liang X, Tor M, Billiar T. The grateful dead: damage-associated molecular pattern molecules and reduction/oxidation regulate immunity. Immunol Rev. 2007; 220:60-81. [PubMed: 17979840]

Luiten RM, Kueter EW, Mooi W, Gallee MP, Rankin EM, Gerritsen WR, Clift SM, Nooijen WJ, Weder P, van de Kasteele WF, Sein J, van den Berk PC, Nieweg OE, Berns AM, Spits H, de Gast GC. Immunogenicity, including vitiligo, and feasibility of vaccination with autologous GMCSF-transduced tumor cells in metastatic melanoma patients. Journal of clinical oncology : official journal of the American Society of Clinical Oncology. 2005; 23:8978-8991. [PubMed: 16260696] 
Lutz E, Yeo CJ, Lillemoe KD, Biedrzycki B, Kobrin B, Herman J, Sugar E, Piantadosi S, Cameron JL, Solt S, Onners B, Tartakovsky I, Choi M, Sharma R, Illei PB, Hruban RH, Abrams RA, Le D, Jaffee E, Laheru D. A lethally irradiated allogeneic granulocyte-macrophage colony stimulating factor-secreting tumor vaccine for pancreatic adenocarcinoma. A Phase II trial of safety, efficacy, and immune activation. Annals of surgery. 2011; 253:328-335. [PubMed: 21217520]

Mach N, Gillessen S, Wilson SB, Sheehan C, Mihm M, Dranoff G. Differences in dendritic cells stimulated in vivo by tumors engineered to secrete granulocyte-macrophage colony-stimulating factor or Flt3-ligand. Cancer research. 2000; 60:3239-3246. [PubMed: 10866317]

Machiels JP, Reilly RT, Emens LA, Ercolini AM, Lei RY, Weintraub D, Okoye FI, Jaffee EM. Cyclophosphamide, doxorubicin, and paclitaxel enhance the antitumor immune response of granulocyte/macrophage-colony stimulating factor-secreting whole-cell vaccines in HER-2/neu tolerized mice. Cancer research. 2001; 61:3689-3697. [PubMed: 11325840]

Madan RA, Gulley JL, Fojo T, Dahut WL. Therapeutic cancer vaccines in prostate cancer: the paradox of improved survival without changes in time to progression. The oncologist. 2010; 15:969-975. [PubMed: 20798195]

Madan RA, Gulley JL, Schlom J, Steinberg SM, Liewehr DJ, Dahut WL, Arlen PM. Analysis of overall survival in patients with nonmetastatic castration-resistant prostate cancer treated with vaccine, nilutamide, and combination therapy. Clinical cancer research : an official journal of the American Association for Cancer Research. 2008; 14:4526-4531. [PubMed: 18628467]

Maecker HT, Umetsu DT, DeKruyff RH, Levy S. Cytotoxic T cell responses to DNA vaccination: dependence on antigen presentation via class II MHC. Journal of immunology. 1998; 161:65326536.

Maldonado-Lopez R, De Smedt T, Michel P, Godfroid J, Pajak B, Heirman C, Thielemans K, Leo O, Urbain J, Moser M. CD8alpha+ and CD8alpha- subclasses of dendritic cells direct the development of distinct T helper cells in vivo. The Journal of experimental medicine. 1999; 189:587-592. [PubMed: 9927520]

Manjili MH, Henderson R, Wang XY, Chen X, Li Y, Repasky E, Kazim L, Subjeck JR. Development of a recombinant HSP110-HER-2/neu vaccine using the chaperoning properties of HSP110. Cancer Res. 2002; 62:1737-1742. [PubMed: 11912148]

Manjili MH, Wang XY, Chen X, Martin T, Repasky EA, Henderson R, Subjeck JR. HSP110-HER2/ neu chaperone complex vaccine induces protective immunity against spontaneous mammary tumors in HER-2/neu transgenic mice. J Immunol. 2003; 171:4054-4061. [PubMed: 14530326]

Mantovani A, Sica A. Macrophages, innate immunity and cancer: balance, tolerance, and diversity. Curr Opin Immunol. 2010; 22:231-237. [PubMed: 20144856]

Marshall JL, Hawkins MJ, Tsang KY, Richmond E, Pedicano JE, Zhu MZ, Schlom J. Phase I study in cancer patients of a replication-defective avipox recombinant vaccine that expresses human carcinoembryonic antigen. Journal of clinical oncology : official journal of the American Society of Clinical Oncology. 1999; 17:332-337. [PubMed: 10458251]

Marshall JL, Hoyer RJ, Toomey MA, Faraguna K, Chang P, Richmond E, Pedicano JE, Gehan E, Peck RA, Arlen P, Tsang KY, Schlom J. Phase I study in advanced cancer patients of a diversified prime-and-boost vaccination protocol using recombinant vaccinia virus and recombinant nonreplicating avipox virus to elicit anti-carcinoembryonic antigen immune responses. Journal of clinical oncology : official journal of the American Society of Clinical Oncology. 2000; 18:3964-3973. [PubMed: 11099326]

Mata-Haro V, Cekic C, Martin M, Chilton PM, Casella CR, Mitchell TC. The vaccine adjuvant monophosphoryl lipid A as a TRIF-biased agonist of TLR4. Science. 2007; 316:1628-1632. [PubMed: 17569868]

Maver C, McKneally M. Preparation of autologous tumor cell vaccine from human lung cancer. Cancer research. 1979; 39:3276. [PubMed: 455310]

Mayer MP, Bukau B. Hsp70 chaperones: cellular functions and molecular mechanism. Cell Mol Life Sci. 2005; 62:670-684. [PubMed: 15770419]

Mazzaferro V, Coppa J, Carrabba MG, Rivoltini L, Schiavo M, Regalia E, Mariani L, Camerini T, Marchiano A, Andreola S, Camerini R, Corsi M, Lewis JJ, Srivastava PK, Parmiani G. Vaccination with autologous tumor-derived heat-shock protein gp96 after liver resection for metastatic colorectal cancer. Clin Cancer Res. 2003; 9:3235-3245. [PubMed: 12960108] 
Mazzoni A, Bronte V, Visintin A, Spitzer JH, Apolloni E, Serafini P, Zanovello P, Segal DM. Myeloid suppressor lines inhibit T cell responses by an NO-dependent mechanism. J Immunol. 2002; 168:689-695. [PubMed: 11777962]

McCarthy EF. The toxins of William B. Coley and the treatment of bone and soft-tissue sarcomas. Iowa Orthop J. 2006; 26:154-158. [PubMed: 16789469]

Mendez R, Ruiz-Cabello F, Rodriguez T, Del Campo A, Paschen A, Schadendorf D, Garrido F. Identification of different tumor escape mechanisms in several metastases from a melanoma patient undergoing immunotherapy. Cancer immunology, immunotherapy : CII. 2007; 56:88-94.

Mercader M, Bodner BK, Moser MT, Kwon PS, Park ES, Manecke RG, Ellis TM, Wojcik EM, Yang D, Flanigan RC, Waters WB, Kast WM, Kwon ED. T cell infiltration of the prostate induced by androgen withdrawal in patients with prostate cancer. Proceedings of the National Academy of Sciences of the United States of America. 2001; 98:14565-14570. [PubMed: 11734652]

Minkis K, Kavanagh DG, Alter G, Bogunovic D, O'Neill D, Adams S, Pavlick A, Walker BD, Brockman MA, Gandhi RT, Bhardwaj N. Type 2 Bias of T cells expanded from the blood of melanoma patients switched to type 1 by IL-12p70 mRNA-transfected dendritic cells. Cancer research. 2008; 68:9441-9450. [PubMed: 19010919]

Mizuno D, Yoshioka O, Akamatu M, Kataoka T. Antitumor effect of intracutaneous injection of bacterial lipopolysaccharide. Cancer research. 1968; 28:1531-1537. [PubMed: 5673568]

Molon B, Ugel S, Del Pozzo F, Soldani C, Zilio S, Avella D, De Palma A, Mauri P, Monegal A, Rescigno M, Savino B, Colombo P, Jonjic N, Pecanic S, Lazzarato L, Fruttero R, Gasco A, Bronte V, Viola A. Chemokine nitration prevents intratumoral infiltration of antigen-specific $\mathrm{T}$ cells. The Journal of experimental medicine. 2011; 208:1949-1962. [PubMed: 21930770]

Morales A, Eidinger D, Bruce AW. Intracavitary Bacillus Calmette-Guerin in the treatment of superficial bladder tumors. J Urol. 1976; 116:180-183. [PubMed: 820877]

Morton DL, Foshag LJ, Hoon DS, Nizze JA, Famatiga E, Wanek LA, Chang C, Davtyan DG, Gupta RK, Elashoff R, et al. Prolongation of survival in metastatic melanoma after active specific immunotherapy with a new polyvalent melanoma vaccine. Ann Surg. 1992; 216:463-482. [PubMed: 1417196]

Morton DL, Hsueh EC, Essner R, Foshag LJ, O'Day SJ, Bilchik A, Gupta RK, Hoon DS, Ravindranath M, Nizze JA, Gammon G, Wanek LA, Wang HJ, Elashoff RM. Prolonged survival of patients receiving active immunotherapy with Canvaxin therapeutic polyvalent vaccine after complete resection of melanoma metastatic to regional lymph nodes. Ann Surg. 2002; 236:438-448. discussion 448-439. [PubMed: 12368672]

Moss B. Genetically engineered poxviruses for recombinant gene expression, vaccination, and safety. Proceedings of the National Academy of Sciences of the United States of America. 1996; 93:11341-11348. [PubMed: 8876137]

Mosser DM, Edwards JP. Exploring the full spectrum of macrophage activation. Nat Rev Immunol. 2008; 8:958-969. [PubMed: 19029990]

Movahedi K, Guilliams M, Van den Bossche J, Van den Bergh R, Gysemans C, Beschin A, De Baetselier P, Van Ginderachter JA. Identification of discrete tumor-induced myeloid-derived suppressor cell subpopulations with distinct T cell-suppressive activity. Blood. 2008; 111:42334244. [PubMed: 18272812]

Murphy G, Tjoa B, Ragde H, Kenny G, Boynton A. Phase I clinical trial: T-cell therapy for prostate cancer using autologous dendritic cells pulsed with HLA-A0201-specific peptides from prostatespecific membrane antigen. The Prostate. 1996; 29:371-380. [PubMed: 8977634]

Murshid A, Gong J, Calderwood SK. Heat-shock proteins in cancer vaccines: agents of antigen crosspresentation. Expert Rev Vaccines. 2008; 7:1019-1030. [PubMed: 18767951]

Murshid A, Gong J, Calderwood SK. Heat shock protein 90 mediates efficient antigen cross presentation through the scavenger receptor expressed by endothelial cells-I. J Immunol. 2010; 185:2903-2917. [PubMed: 20686127]

Nair SK, Morse M, Boczkowski D, Cumming RI, Vasovic L, Gilboa E, Lyerly HK. Induction of tumor-specific cytotoxic T lymphocytes in cancer patients by autologous tumor RNA-transfected dendritic cells. Ann Surg. 2002; 235:540-549. [PubMed: 11923611] 
Nemunaitis J. Granulocyte-macrophage colony-stimulating factor gene-transfected autologous tumor cell vaccine: focus[correction to fcous] on non-small-cell lung cancer. Clin Lung Cancer. 2003; 5:148-157. [PubMed: 14667270]

Nemunaitis J, Dillman RO, Schwarzenberger PO, Senzer N, Cunningham C, Cutler J, Tong A, Kumar P, Pappen B, Hamilton C, DeVol E, Maples PB, Liu L, Chamberlin T, Shawler DL, Fakhrai H. Phase II study of belagenpumatucel-L, a transforming growth factor beta-2 antisense genemodified allogeneic tumor cell vaccine in non-small-cell lung cancer. J Clin Oncol. 2006; 24:4721-4730. [PubMed: 16966690]

Nemunaitis J, Nemunaitis M, Senzer N, Snitz P, Bedell C, Kumar P, Pappen B, Maples PB, Shawler D, Fakhrai H. Phase II trial of Belagenpumatucel-L, a TGF-beta2 antisense gene modified allogeneic tumor vaccine in advanced non small cell lung cancer (NSCLC) patients. Cancer Gene Ther. 2009; 16:620-624. [PubMed: 19287371]

Nemunaitis J, Sterman D, Jablons D, Smith JW 2nd, Fox B, Maples P, Hamilton S, Borellini F, Lin A, Morali S, Hege K. Granulocyte-macrophage colony-stimulating factor gene-modified autologous tumor vaccines in non-small-cell lung cancer. J Natl Cancer Inst. 2004; 96:326-331. [PubMed: 14970281]

Nestle FO, Alijagic S, Gilliet M, Sun Y, Grabbe S, Dummer R, Burg G, Schadendorf D. Vaccination of melanoma patients with peptide- or tumor lysate-pulsed dendritic cells. Nat Med. 1998; 4:328-332. [PubMed: 9500607]

Niethammer AG, Xiang R, Becker JC, Wodrich H, Pertl U, Karsten G, Eliceiri BP, Reisfeld RA. A DNA vaccine against VEGF receptor 2 prevents effective angiogenesis and inhibits tumor growth. Nat Med. 2002; 8:1369-1375. [PubMed: 12415261]

Nishikawa H, Kato T, Tawara I, Saito K, Ikeda H, Kuribayashi K, Allen PM, Schreiber RD, Sakaguchi S, Old LJ, Shiku H. Definition of target antigens for naturally occurring CD4(+) CD25(+) regulatory T cells. The Journal of experimental medicine. 2005; 201:681-686. [PubMed: 15753203]

Ockert D, Schirrmacher V, Beck N, Stoelben E, Ahlert T, Flechtenmacher J, Hagmuller E, Buchcik R, Nagel M, Saeger HD. Newcastle disease virus-infected intact autologous tumor cell vaccine for adjuvant active specific immunotherapy of resected colorectal carcinoma. Clinical cancer research : an official journal of the American Association for Cancer Research. 1996; 2:21-28. [PubMed: 9816085]

Ogawa F, Iinuma H, Okinaga K. Dendritic cell vaccine therapy by immunization with fusion cells of interleukin-2 gene-transduced, spleen-derived dendritic cells and tumour cells. Scand J Immunol. 2004; 59:432-439. [PubMed: 15140052]

Oh HJ, Chen X, Subjeck JR. Hsp110 protects heat-denatured proteins and confers cellular thermoresistance. J Biol Chem. 1997; 272:31636-31640. [PubMed: 9395504]

Ohtani M, Nagai S, Kondo S, Mizuno S, Nakamura K, Tanabe M, Takeuchi T, Matsuda S, Koyasu S. Mammalian target of rapamycin and glycogen synthase kinase 3 differentially regulate lipopolysaccharide-induced interleukin-12 production in dendritic cells. Blood. 2008; 112:635643. [PubMed: 18492954]

Okada H, Kalinski P, Ueda R, Hoji A, Kohanbash G, Donegan TE, Mintz AH, Engh JA, Bartlett DL, Brown CK, Zeh H, Holtzman MP, Reinhart TA, Whiteside TL, Butterfield LH, Hamilton RL, Potter DM, Pollack IF, Salazar AM, Lieberman FS. Induction of CD8+ T-cell responses against novel glioma-associated antigen peptides and clinical activity by vaccinations with $\{$ alpha $\}$-type 1 polarized dendritic cells and polyinosinic-polycytidylic acid stabilized by lysine and carboxymethylcellulose in patients with recurrent malignant glioma. Journal of clinical oncology : official journal of the American Society of Clinical Oncology. 2011; 29:330-336. [PubMed: 21149657]

Okada N, Mori N, Koretomo R, Okada Y, Nakayama T, Yoshie O, Mizuguchi H, Hayakawa T, Nakagawa S, Mayumi T, Fujita T, Yamamoto A. Augmentation of the migratory ability of DCbased vaccine into regional lymph nodes by efficient CCR7 gene transduction. Gene Ther. 2005; 12:129-139. [PubMed: 15483669]

Orlandi F, Guevara-Patino JA, Merghoub T, Wolchok JD, Houghton AN, Gregor PD. Combination of epitope-optimized DNA vaccination and passive infusion of monoclonal antibody against HER2/ 
neu leads to breast tumor regression in mice. Vaccine. 2011; 29:3646-3654. [PubMed: 21435405]

Oshiumi H, Matsumoto M, Funami K, Akazawa T, Seya T. TICAM-1, an adaptor molecule that participates in Toll-like receptor 3-mediated interferon-beta induction. Nat Immunol. 2003; 4:161-167. [PubMed: 12539043]

Oudard S, Rixe O, Beuselinck B, Linassier C, Banu E, Machiels JP, Baudard M, Ringeisen F, Velu T, Lefrere-Belda MA, Limacher JM, Fridman WH, Azizi M, Acres B, Tartour E. A phase II study of the cancer vaccine TG4010 alone and in combination with cytokines in patients with metastatic renal clear-cell carcinoma: clinical and immunological findings. Cancer immunology, immunotherapy : CII. 2011; 60:261-271.

Pace L, Vitale S, Dettori B, Palombi C, La Sorsa V, Belardelli F, Proietti E, Doria G. APC activation by IFN-alpha decreases regulatory $\mathrm{T}$ cell and enhances Th cell functions. Journal of immunology. 2010; 184:5969-5979.

Palmer DC, Restifo NP. Suppressors of cytokine signaling (SOCS) in T cell differentiation, maturation, and function. Trends Immunol. 2009; 30:592-602. [PubMed: 19879803]

Palucka AK, Ueno H, Connolly J, Kerneis-Norvell F, Blanck JP, Johnston DA, Fay J, Banchereau J. Dendritic cells loaded with killed allogeneic melanoma cells can induce objective clinical responses and MART-1 specific CD8+ T-cell immunity. J Immunother. 2006; 29:545-557. [PubMed: 16971810]

Pan PY, Ma G, Weber KJ, Ozao-Choy J, Wang G, Yin B, Divino CM, Chen SH. Immune stimulatory receptor $\mathrm{CD} 40$ is required for $\mathrm{T}$-cell suppression and $\mathrm{T}$ regulatory cell activation mediated by myeloid-derived suppressor cells in cancer. Cancer research. 2010; 70:99-108. [PubMed: 19996287]

Pardoll D. Does the immune system see tumors as foreign or self? Annual review of immunology. 2003; 21:807-839.

Park J, Easton DP, Chen X, MacDonald IJ, Wang XY, Subjeck JR. The chaperoning properties of mouse grp170, a member of the third family of hsp70 related proteins. Biochemistry. 2003; 42:14893-14902. [PubMed: 14674765]

Park J, Facciponte JG, Chen X, MacDonald IJ, Repasky E, Manjili MH, Wang XY, Subjeck JR. Chaperoning Function of Stress Protein grp170, a Member of the hsp70 Superfamily, Is Responsible for its Immunoadjuvant Activity. Cancer Res. 2006; 66:1161-1168. [PubMed: 16424054]

Parkhurst MR, Fitzgerald EB, Southwood S, Sette A, Rosenberg SA, Kawakami Y. Identification of a shared HLA-A*0201-restricted T-cell epitope from the melanoma antigen tyrosinase-related protein 2 (TRP2). Cancer Res. 1998; 58:4895-4901. [PubMed: 9809996]

Parmiani G, De Filippo A, Novellino L, Castelli C. Unique human tumor antigens: immunobiology and use in clinical trials. Journal of immunology. 2007; 178:1975-1979.

Peggs KS, Segal NH, Allison JP. Targeting immunosupportive cancer therapies: accentuate the positive, eliminate the negative. Cancer Cell. 2007; 12:192-199. [PubMed: 17785201]

Pellegrini M, Calzascia T, Elford AR, Shahinian A, Lin AE, Dissanayake D, Dhanji S, Nguyen LT, Gronski MA, Morre M, Assouline B, Lahl K, Sparwasser T, Ohashi PS, Mak TW. Adjuvant IL-7 antagonizes multiple cellular and molecular inhibitory networks to enhance immunotherapies. Nat Med. 2009; 15:528-536. [PubMed: 19396174]

Peranzoni E, Zilio S, Marigo I, Dolcetti L, Zanovello P, Mandruzzato S, Bronte V. Myeloid-derived suppressor cell heterogeneity and subset definition. Curr Opin Immunol. 2010; 22:238-244. [PubMed: 20171075]

Pilla L, Patuzzo R, Rivoltini L, Maio M, Pennacchioli E, Lamaj E, Maurichi A, Massarut S, Marchiano A, Santantonio C, Tosi D, Arienti F, Cova A, Sovena G, Piris A, Nonaka D, Bersani I, Di Florio A, Luigi M, Srivastava PK, Hoos A, Santinami M, Parmiani G. A phase II trial of vaccination with autologous, tumor-derived heat-shock protein peptide complexes Gp96, in combination with GM-CSF and interferon-alpha in metastatic melanoma patients. Cancer immunology, immunotherapy : CII. 2006; 55:958-968.

Plaksin D, Porgador A, Vadai E, Feldman M, Schirrmacher V, Eisenbach L. Effective anti-metastatic melanoma vaccination with tumor cells transfected with MHC genes and/or infected with 
Newcastle disease virus (NDV). International journal of cancer. Journal international du cancer. 1994; 59:796-801. [PubMed: 7989121]

Polyak K, Weinberg RA. Transitions between epithelial and mesenchymal states: acquisition of malignant and stem cell traits. Nature reviews. Cancer. 2009; 9:265-273. [PubMed: 19262571]

Prigal SJ. Development in mice of prolonged non-specific resistance to sarcoma implant and Staphylococcus infection following repository injection of lipopolysaccharide. Nature. 1961; 191:1111-1112. [PubMed: 13738017]

Pulendran B, Smith JL, Caspary G, Brasel K, Pettit D, Maraskovsky E, Maliszewski CR. Distinct dendritic cell subsets differentially regulate the class of immune response in vivo. Proceedings of the National Academy of Sciences of the United States of America. 1999; 96:1036-1041. [PubMed: 9927689]

Qian B, Deng Y, Im JH, Muschel RJ, Zou Y, Li J, Lang RA, Pollard JW. A distinct macrophage population mediates metastatic breast cancer cell extravasation, establishment and growth. PLoS One. 2009; 4:e6562. [PubMed: 19668347]

Qian BZ, Pollard JW. Macrophage diversity enhances tumor progression and metastasis. Cell. 2010; 141:39-51. [PubMed: 20371344]

Qian J, Yi H, Guo C, Yu X, Zuo D, Chen X, Kane JM 3rd, Repasky EA, Subjeck JR, Wang XY. CD204 suppresses large heat shock protein-facilitated priming of tumor antigen gp100-specific T cells and chaperone vaccine activity against mouse melanoma. J Immunol. 2011; 187:29052914. [PubMed: 21832164]

Qiu P, Ziegelhoffer P, Sun J, Yang NS. Gene gun delivery of mRNA in situ results in efficient transgene expression and genetic immunization. Gene Ther. 1996; 3:262-268. [PubMed: 8646558]

Quezada SA, Jarvinen LZ, Lind EF, Noelle RJ. CD40/CD154 interactions at the interface of tolerance and immunity. Annual review of immunology. 2004; 22:307-328.

Quezada SA, Peggs KS, Curran MA, Allison JP. CTLA4 blockade and GM-CSF combination immunotherapy alters the intratumor balance of effector and regulatory T cells. J Clin Invest. 2006; 116:1935-1945. [PubMed: 16778987]

Quoix E, Ramlau R, Westeel V, Papai Z, Madroszyk A, Riviere A, Koralewski P, Breton JL, Stoelben E, Braun D, Debieuvre D, Lena H, Buyse M, Chenard MP, Acres B, Lacoste G, Bastien B, Tavernaro A, Bizouarne N, Bonnefoy JY, Limacher JM. Therapeutic vaccination with TG4010 and first-line chemotherapy in advanced non-small-cell lung cancer: a controlled phase $2 \mathrm{~B}$ trial. The lancet oncology. 2011; 12:1125-1133. [PubMed: 22019520]

Racanelli V, Leone P, Frassanito MA, Brunetti C, Perosa F, Ferrone S, Dammacco F. Alterations in the antigen processing-presenting machinery of transformed plasma cells are associated with reduced recognition by CD8+ T cells and characterize the progression of MGUS to multiple myeloma. Blood. 2010; 115:1185-1193. [PubMed: 20008301]

Raty JK, Pikkarainen JT, Wirth T, Yla-Herttuala S. Gene therapy: the first approved gene-based medicines, molecular mechanisms and clinical indications. Curr Mol Pharmacol. 2008; 1:13-23. [PubMed: 20021420]

Raychaudhuri B, Rayman P, Ireland J, Ko J, Rini B, Borden EC, Garcia J, Vogelbaum MA, Finke J. Myeloid-derived suppressor cell accumulation and function in patients with newly diagnosed glioblastoma. Neuro-oncology. 2011; 13:591-599. [PubMed: 21636707]

Reits EA, Hodge JW, Herberts CA, Groothuis TA, Chakraborty M, Wansley EK, Camphausen K, Luiten RM, de Ru AH, Neijssen J, Griekspoor A, Mesman E, Verreck FA, Spits H, Schlom J, van Veelen P, Neefjes JJ. Radiation modulates the peptide repertoire, enhances MHC class I expression, and induces successful antitumor immunotherapy. J Exp Med. 2006; 203:1259-1271. [PubMed: 16636135]

Remondo C, Cereda V, Mostbock S, Sabzevari H, Franzusoff A, Schlom J, Tsang KY. Human dendritic cell maturation and activation by a heat-killed recombinant yeast (Saccharomyces cerevisiae) vector encoding carcinoembryonic antigen. Vaccine. 2009; 27:987-994. [PubMed: 19110021]

Respa A, Bukur J, Ferrone S, Pawelec G, Zhao Y, Wang E, Marincola FM, Seliger B. Association of IFN-gamma signal transduction defects with impaired HLA class I antigen processing in 
melanoma cell lines. Clinical cancer research : an official journal of the American Association for Cancer Research. 2011; 17:2668-2678. [PubMed: 21248298]

Ribas A, Weber JS, Chmielowski B, Comin-Anduix B, Lu D, Douek M, Ragavendra N, Raman S, Seja E, Rosario D, Miles S, Diamond DC, Qiu Z, Obrocea M, Bot A. Intra-lymph node prime-boost vaccination against Melan $A$ and tyrosinase for the treatment of metastatic melanoma: results of a phase 1 clinical trial. Clinical cancer research : an official journal of the American Association for Cancer Research. 2011; 17:2987-2996. [PubMed: 21385924]

Rice J, Buchan S, Stevenson FK. Critical components of a DNA fusion vaccine able to induce protective cytotoxic $\mathrm{T}$ cells against a single epitope of a tumor antigen. Journal of immunology. 2002; 169:3908-3913.

Rice J, Dunn S, Piper K, Buchan SL, Moss PA, Stevenson FK. DNA fusion vaccines induce epitopespecific cytotoxic CD8(+) T cells against human leukemia-associated minor histocompatibility antigens. Cancer research. 2006; 66:5436-5442. [PubMed: 16707472]

Rice J, Elliott T, Buchan S, Stevenson FK. DNA fusion vaccine designed to induce cytotoxic T cell responses against defined peptide motifs: implications for cancer vaccines. Journal of immunology. 2001; 167:1558-1565.

Rice J, Ottensmeier CH, Stevenson FK. DNA vaccines: precision tools for activating effective immunity against cancer. Nat Rev Cancer. 2008; 8:108-120. [PubMed: 18219306]

Rider P, Carmi Y, Guttman O, Braiman A, Cohen I, Voronov E, White MR, Dinarello CA, Apte RN. IL-1alpha and IL-1beta recruit different myeloid cells and promote different stages of sterile inflammation. Journal of immunology. 2011; 187:4835-4843.

Rivoltini L, Castelli C, Carrabba M, Mazzaferro V, Pilla L, Huber V, Coppa J, Gallino G, Scheibenbogen C, Squarcina P, Cova A, Camerini R, Lewis JJ, Srivastava PK, Parmiani G. Human tumor-derived heat shock protein 96 mediates in vitro activation and in vivo expansion of melanoma- and colon carcinoma-specific T cells. J Immunol. 2003; 171:3467-3474. [PubMed: 14500642]

Rodriguez PC, Quiceno DG, Zabaleta J, Ortiz B, Zea AH, Piazuelo MB, Delgado A, Correa P, Brayer J, Sotomayor EM, Antonia S, Ochoa JB, Ochoa AC. Arginase I production in the tumor microenvironment by mature myeloid cells inhibits T-cell receptor expression and antigenspecific T-cell responses. Cancer research. 2004; 64:5839-5849. [PubMed: 15313928]

Romano E, Rossi M, Ratzinger G, de Cos MA, Chung DJ, Panageas KS, Wolchok JD, Houghton AN, Chapman PB, Heller G, Yuan J, Young JW. Peptide-loaded Langerhans cells, despite increased IL15 secretion and T-cell activation in vitro, elicit antitumor T-cell responses comparable to peptide-loaded monocyte-derived dendritic cells in vivo. Clin Cancer Res. 2011; 17:1984-1997. [PubMed: 21355077]

Rosenberg SA, Yang JC, Schwartzentruber DJ, Hwu P, Marincola FM, Topalian SL, Restifo NP, Dudley ME, Schwarz SL, Spiess PJ, Wunderlich JR, Parkhurst MR, Kawakami Y, Seipp CA, Einhorn JH, White DE. Immunologic and therapeutic evaluation of a synthetic peptide vaccine for the treatment of patients with metastatic melanoma. Nat Med. 1998; 4:321-327. [PubMed: 9500606]

Rosenberg SA, Yannelli JR, Yang JC, Topalian SL, Schwartzentruber DJ, Weber JS, Parkinson DR, Seipp CA, Einhorn JH, White DE. Treatment of patients with metastatic melanoma with autologous tumor-infiltrating lymphocytes and interleukin 2. J Natl Cancer Inst. 1994; 86:11591166. [PubMed: 8028037]

Rosenblatt J, Vasir B, Uhl L, Blotta S, Macnamara C, Somaiya P, Wu Z, Joyce R, Levine JD, Dombagoda D, Yuan YE, Francoeur K, Fitzgerald D, Richardson P, Weller E, Anderson K, Kufe D, Munshi N, Avigan D. Vaccination with dendritic cell/tumor fusion cells results in cellular and humoral antitumor immune responses in patients with multiple myeloma. Blood. 2011; 117:393402. [PubMed: 21030562]

Ruan Z, Yang Z, Wang Y, Wang H, Chen Y, Shang X, Yang C, Guo S, Han J, Liang H, Wu Y. DNA vaccine against tumor endothelial marker 8 inhibits tumor angiogenesis and growth. $J$ Immunother. 2009; 32:486-491. [PubMed: 19609240]

Ruttinger D, van den Engel NK, Winter H, Schlemmer M, Pohla H, Grutzner S, Wagner B, Schendel DJ, Fox BA, Jauch KW, Hatz RA. Adjuvant therapeutic vaccination in patients with non-small cell lung cancer made lymphopenic and reconstituted with autologous PBMC: first clinical 
experience and evidence of an immune response. Journal of translational medicine. 2007; 5:43. [PubMed: 17868452]

Sakaguchi S. Naturally arising CD4+ regulatory t cells for immunologic self-tolerance and negative control of immune responses. Annu Rev Immunol. 2004; 22:531-562. [PubMed: 15032588]

Sakuishi K, Apetoh L, Sullivan JM, Blazar BR, Kuchroo VK, Anderson AC. Targeting Tim-3 and PD-1 pathways to reverse T cell exhaustion and restore anti-tumor immunity. The Journal of experimental medicine. 2010; 207:2187-2194. [PubMed: 20819927]

Salcedo M, Bercovici N, Taylor R, Vereecken P, Massicard S, Duriau D, Vernel-Pauillac F, Boyer A, Baron-Bodo V, Mallard E, Bartholeyns J, Goxe B, Latour N, Leroy S, Prigent D, Martiat P, Sales F, Laporte M, Bruyns C, Romet-Lemonne JL, Abastado JP, Lehmann F, Velu T. Vaccination of melanoma patients using dendritic cells loaded with an allogeneic tumor cell lysate. Cancer Immunol Immunother. 2006; 55:819-829. [PubMed: 16187085]

Salgia R, Lynch T, Skarin A, Lucca J, Lynch C, Jung K, Hodi FS, Jaklitsch M, Mentzer S, Swanson S, Lukanich J, Bueno R, Wain J, Mathisen D, Wright C, Fidias P, Donahue D, Clift S, Hardy S, Neuberg D, Mulligan R, Webb I, Sugarbaker D, Mihm M, Dranoff G. Vaccination with irradiated autologous tumor cells engineered to secrete granulocyte-macrophage colonystimulating factor augments antitumor immunity in some patients with metastatic non-small-cell lung carcinoma. Journal of clinical oncology : official journal of the American Society of Clinical Oncology. 2003; 21:624-630. [PubMed: 12586798]

Sampson JH, Archer GE, Ashley DM, Fuchs HE, Hale LP, Dranoff G, Bigner DD. Subcutaneous vaccination with irradiated, cytokine-producing tumor cells stimulates CD8+ cell-mediated immunity against tumors located in the "immunologically privileged" central nervous system. Proceedings of the National Academy of Sciences of the United States of America. 1996; 93:10399-10404. [PubMed: 8816812]

Sato E, Olson SH, Ahn J, Bundy B, Nishikawa H, Qian F, Jungbluth AA, Frosina D, Gnjatic S, Ambrosone C, Kepner J, Odunsi T, Ritter G, Lele S, Chen YT, Ohtani H, Old LJ, Odunsi K. Intraepithelial CD8+ tumor-infiltrating lymphocytes and a high CD8+/regulatory $\mathrm{T}$ cell ratio are associated with favorable prognosis in ovarian cancer. Proceedings of the National Academy of Sciences of the United States of America. 2005; 102:18538-18543. [PubMed: 16344461]

Savelyeva N, Munday R, Spellerberg MB, Lomonossoff GP, Stevenson FK. Plant viral genes in DNA idiotypic vaccines activate linked CD4+ T-cell mediated immunity against B-cell malignancies. Nat Biotechnol. 2001; 19:760-764. [PubMed: 11479570]

Scheel B, Braedel S, Probst J, Carralot JP, Wagner H, Schild H, Jung G, Rammensee HG, Pascolo S. Immunostimulating capacities of stabilized RNA molecules. Eur J Immunol. 2004; 34:537-547. [PubMed: 14768059]

Scheel B, Teufel R, Probst J, Carralot JP, Geginat J, Radsak M, Jarrossay D, Wagner H, Jung G, Rammensee HG, Hoerr I, Pascolo S. Toll-like receptor-dependent activation of several human blood cell types by protamine-condensed mRNA. Eur J Immunol. 2005; 35:1557-1566. [PubMed: 15832293]

Schiffman M, Wacholder S. Success of HPV vaccination is now a matter of coverage. The lancet oncology. 2012; 13:10-12. [PubMed: 22075169]

Schirrmacher V. Clinical trials of antitumor vaccination with an autologous tumor cell vaccine modified by virus infection: improvement of patient survival based on improved antitumor immune memory. Cancer Immunol Immunother. 2005; 54:587-598. [PubMed: 15838708]

Schmidt SM, Schag K, Muller MR, Weck MM, Appel S, Kanz L, Grunebach F, Brossart P. Survivin is a shared tumor-associated antigen expressed in a broad variety of malignancies and recognized by specific cytotoxic T cells. Blood. 2003; 102:571-576. [PubMed: 12576330]

Schmielau J, Finn OJ. Activated granulocytes and granulocyte-derived hydrogen peroxide are the underlying mechanism of suppression of t-cell function in advanced cancer patients. Cancer research. 2001; 61:4756-4760. [PubMed: 11406548]

Schmollinger JC, Vonderheide RH, Hoar KM, Maecker B, Schultze JL, Hodi FS, Soiffer RJ, Jung K, Kuroda MJ, Letvin NL, Greenfield EA, Mihm M, Kutok JL, Dranoff G. Melanoma inhibitor of apoptosis protein (ML-IAP) is a target for immune-mediated tumor destruction. Proc Natl Acad Sci U S A. 2003; 100:3398-3403. [PubMed: 12626761] 
Schreiber RD, Old LJ, Smyth MJ. Cancer immunoediting: integrating immunity's roles in cancer suppression and promotion. Science. 2011; 331:1565-1570. [PubMed: 21436444]

Schuler-Thurner B, Schultz ES, Berger TG, Weinlich G, Ebner S, Woerl P, Bender A, Feuerstein B, Fritsch PO, Romani N, Schuler G. Rapid induction of tumor-specific type 1 T helper cells in metastatic melanoma patients by vaccination with mature, cryopreserved, peptide-loaded monocyte-derived dendritic cells. J Exp Med. 2002; 195:1279-1288. [PubMed: 12021308]

Schulof RS, Mai D, Nelson MA, Paxton HM, Cox JW Jr. Turner ML, Mills M, Hix WR, Nochomovitz LE, Peters LC, et al. Active specific immunotherapy with an autologous tumor cell vaccine in patients with resected non-small cell lung cancer. Mol Biother. 1988; 1:30-36. [PubMed: 2855788]

Schwartzentruber DJ, Lawson DH, Richards JM, Conry RM, Miller DM, Treisman J, Gailani F, Riley L, Conlon K, Pockaj B, Kendra KL, White RL, Gonzalez R, Kuzel TM, Curti B, Leming PD, Whitman ED, Balkissoon J, Reintgen DS, Kaufman H, Marincola FM, Merino MJ, Rosenberg SA, Choyke P, Vena D, Hwu P. gp100 peptide vaccine and interleukin-2 in patients with advanced melanoma. The New England journal of medicine. 2011; 364:2119-2127. [PubMed: 21631324]

Schwarz TF. Clinical update of the AS04-adjuvanted human papillomavirus-16/18 cervical cancer vaccine, Cervarix. Advances in therapy. 2009; 26:983-998. [PubMed: 20024678]

Seliger B, Stoehr R, Handke D, Mueller A, Ferrone S, Wullich B, Tannapfel A, Hofstaedter F, Hartmann A. Association of HLA class I antigen abnormalities with disease progression and early recurrence in prostate cancer. Cancer immunology, immunotherapy : CII. 2010; 59:529540.

Senzer NN, Kaufman HL, Amatruda T, Nemunaitis M, Reid T, Daniels G, Gonzalez R, Glaspy J, Whitman E, Harrington K, Goldsweig H, Marshall T, Love C, Coffin R, Nemunaitis JJ. Phase II clinical trial of a granulocyte-macrophage colony-stimulating factor-encoding, second-generation oncolytic herpesvirus in patients with unresectable metastatic melanoma. Journal of clinical oncology : official journal of the American Society of Clinical Oncology. 2009; 27:5763-5771. [PubMed: 19884534]

Serafini P, Carbley R, Noonan KA, Tan G, Bronte V, Borrello I. High-dose granulocyte-macrophage colony-stimulating factor-producing vaccines impair the immune response through the recruitment of myeloid suppressor cells. Cancer Res. 2004; 64:6337-6343. [PubMed: 15342423]

Shen L, Evel-Kabler K, Strube R, Chen SY. Silencing of SOCS1 enhances antigen presentation by dendritic cells and antigen-specific anti-tumor immunity. Nat Biotechnol. 2004; 22:1546-1553. [PubMed: 15558048]

Shevach EM. CD4+ CD25+ suppressor T cells: more questions than answers. Nature reviews. Immunology. 2002; 2:389-400. [PubMed: 12093005]

Sikora AG, Jaffarzad N, Hailemichael Y, Gelbard A, Stonier SW, Schluns KS, Frasca L, Lou Y, Liu C, Andersson HA, Hwu P, Overwijk WW. IFN-alpha enhances peptide vaccine-induced CD8+ T cell numbers, effector function, and antitumor activity. Journal of immunology. 2009; 182:73987407.

Simons JW, Carducci MA, Mikhak B, Lim M, Biedrzycki B, Borellini F, Clift SM, Hege KM, Ando DG, Piantadosi S, Mulligan R, Nelson WG. Phase I/II trial of an allogeneic cellular immunotherapy in hormone-naive prostate cancer. Clinical cancer research : an official journal of the American Association for Cancer Research. 2006; 12:3394-3401. [PubMed: 16740763]

Singh R, Paterson Y. Listeria monocytogenes as a vector for tumor-associated antigens for cancer immunotherapy. Expert review of vaccines. 2006; 5:541-552. [PubMed: 16989634]

Singh R, Paterson Y. In the FVB/N HER-2/neu transgenic mouse both peripheral and central tolerance limit the immune response targeting HER-2/neu induced by Listeria monocytogenes-based vaccines. Cancer immunology, immunotherapy : CII. 2007; 56:927-938.

Slingluff CL Jr. Petroni GR, Olson WC, Smolkin ME, Ross MI, Haas NB, Grosh WW, Boisvert ME, Kirkwood JM, Chianese-Bullock KA. Effect of granulocyte/macrophage colony-stimulating factor on circulating CD8+ and CD4+ T-cell responses to a multipeptide melanoma vaccine: outcome of a multicenter randomized trial. Clinical cancer research : an official journal of the American Association for Cancer Research. 2009; 15:7036-7044. [PubMed: 19903780] 
Sloots A, Mastini C, Rohrbach F, Weth R, Curcio C, Burkhardt U, Jager E, Forni G, Cavallo F, Wels WS. DNA vaccines targeting tumor antigens to B7 molecules on antigen-presenting cells induce protective antitumor immunity and delay onset of HER-2/Neu-driven mammary carcinoma. Clinical cancer research : an official journal of the American Association for Cancer Research. 2008; 14:6933-6943. [PubMed: 18980988]

Small EJ, Fratesi P, Reese DM, Strang G, Laus R, Peshwa MV, Valone FH. Immunotherapy of hormone-refractory prostate cancer with antigen-loaded dendritic cells. J Clin Oncol. 2000; 18:3894-3903. [PubMed: 11099318]

Small EJ, Sacks N, Nemunaitis J, Urba WJ, Dula E, Centeno AS, Nelson WG, Ando D, Howard C, Borellini F, Nguyen M, Hege K, Simons JW. Granulocyte macrophage colony-stimulating factor--secreting allogeneic cellular immunotherapy for hormone-refractory prostate cancer. Clinical cancer research : an official journal of the American Association for Cancer Research. 2007; 13:3883-3891. [PubMed: 17606721]

Small EJ, Schellhammer PF, Higano CS, Redfern CH, Nemunaitis JJ, Valone FH, Verjee SS, Jones LA, Hershberg RM. Placebo-controlled phase III trial of immunologic therapy with sipuleucel-T (APC8015) in patients with metastatic, asymptomatic hormone refractory prostate cancer. Journal of clinical oncology : official journal of the American Society of Clinical Oncology. 2006; 24:3089-3094. [PubMed: 16809734]

Soiffer R, Hodi FS, Haluska F, Jung K, Gillessen S, Singer S, Tanabe K, Duda R, Mentzer S, Jaklitsch M, Bueno R, Clift S, Hardy S, Neuberg D, Mulligan R, Webb I, Mihm M, Dranoff G. Vaccination with irradiated, autologous melanoma cells engineered to secrete granulocytemacrophage colony-stimulating factor by adenoviral-mediated gene transfer augments antitumor immunity in patients with metastatic melanoma. J Clin Oncol. 2003; 21:3343-3350. [PubMed: 12947071]

Soiffer R, Lynch T, Mihm M, Jung K, Rhuda C, Schmollinger JC, Hodi FS, Liebster L, Lam P, Mentzer S, Singer S, Tanabe KK, Cosimi AB, Duda R, Sober A, Bhan A, Daley J, Neuberg D, Parry G, Rokovich J, Richards L, Drayer J, Berns A, Clift S, Cohen LK, Mulligan RC, Dranoff G. Vaccination with irradiated autologous melanoma cells engineered to secrete human granulocyte-macrophage colony-stimulating factor generates potent antitumor immunity in patients with metastatic melanoma. Proc Natl Acad Sci U S A. 1998; 95:13141-13146. [PubMed: 9789055]

Sondak VK, Sabel MS, Mule JJ. Allogeneic and autologous melanoma vaccines: where have we been and where are we going? Clin Cancer Res. 2006; 12:2337s-2341s. [PubMed: 16609055]

Song XT, Evel-Kabler K, Shen L, Rollins L, Huang XF, Chen SY. A20 is an antigen presentation attenuator, and its inhibition overcomes regulatory T cell-mediated suppression. Nat Med. 2008; 14:258-265. [PubMed: 18311150]

Sosman JA, Carrillo C, Urba WJ, Flaherty L, Atkins MB, Clark JI, Dutcher J, Margolin KA, Mier J, Gollob J, Kirkwood JM, Panka DJ, Crosby NA, O'Boyle K, LaFleur B, Ernstoff MS. Three phase II cytokine working group trials of gp100 (210M) peptide plus high-dose interleukin-2 in patients with HLA-A2-positive advanced melanoma. Journal of clinical oncology : official journal of the American Society of Clinical Oncology. 2008; 26:2292-2298. [PubMed: 18467720]

Spellerberg MB, Zhu D, Thompsett A, King CA, Hamblin TJ, Stevenson FK. DNA vaccines against lymphoma: promotion of anti-idiotypic antibody responses induced by single chain Fv genes by fusion to tetanus toxin fragment C. Journal of immunology. 1997; 159:1885-1892.

Spies B, Hochrein H, Vabulas M, Huster K, Busch DH, Schmitz F, Heit A, Wagner H. Vaccination with plasmid DNA activates dendritic cells via Toll-like receptor 9 (TLR9) but functions in TLR9-deficient mice. Journal of immunology. 2003; 171:5908-5912.

Spisek R, Kukreja A, Chen LC, Matthews P, Mazumder A, Vesole D, Jagannath S, Zebroski HA, Simpson AJ, Ritter G, Durie B, Crowley J, Shaughnessy JD Jr. Scanlan MJ, Gure AO, Barlogie B, Dhodapkar MV. Frequent and specific immunity to the embryonal stem cell-associated antigen SOX2 in patients with monoclonal gammopathy. The Journal of experimental medicine. 2007; 204:831-840. [PubMed: 17389240]

Srivastava MK, Sinha P, Clements VK, Rodriguez P, Ostrand-Rosenberg S. Myeloid-derived suppressor cells inhibit T-cell activation by depleting cystine and cysteine. Cancer research. 2010; 70:68-77. [PubMed: 20028852] 
Srivastava P. Interaction of heat shock proteins with peptides and antigen presenting cells: chaperoning of the innate and adaptive immune responses. Annu Rev Immunol. 2002a; 20:395-425. [PubMed: 11861608]

Srivastava P. Roles of heat-shock proteins in innate and adaptive immunity. Nat Rev Immunol. 2002b; 2:185-194. [PubMed: 11913069]

Srivastava PK. Immunotherapy for human cancer using heat shock protein-peptide complexes. Curr Oncol Rep. 2005; 7:104-108. [PubMed: 15717943]

Srivastava PK, DeLeo AB, Old LJ. Tumor rejection antigens of chemically induced sarcomas of inbred mice. Proc Natl Acad Sci U S A. 1986; 83:3407-3411. [PubMed: 3458189]

Steele JC, Rao A, Marsden JR, Armstrong CJ, Berhane S, Billingham LJ, Graham N, Roberts C, Ryan G, Uppal H, Walker C, Young LS, Steven NM. Phase I/II trial of a dendritic cell vaccine transfected with DNA encoding melan A and gp100 for patients with metastatic melanoma. Gene Ther. 2011; 18:584-593. [PubMed: 21307889]

Stein WD, Gulley JL, Schlom J, Madan RA, Dahut W, Figg WD, Ning YM, Arlen PM, Price D, Bates SE, Fojo T. Tumor regression and growth rates determined in five intramural NCI prostate cancer trials: the growth rate constant as an indicator of therapeutic efficacy. Clinical cancer research : an official journal of the American Association for Cancer Research. 2011; 17:907-917. [PubMed: 21106727]

Steiner HH, Bonsanto MM, Beckhove P, Brysch M, Geletneky K, Ahmadi R, Schuele-Freyer R, Kremer P, Ranaie G, Matejic D, Bauer H, Kiessling M, Kunze S, Schirrmacher V, Herold-Mende C. Antitumor vaccination of patients with glioblastoma multiforme: a pilot study to assess feasibility, safety, and clinical benefit. Journal of clinical oncology : official journal of the American Society of Clinical Oncology. 2004; 22:4272-4281. [PubMed: 15452186]

Stratford R, Douce G, Zhang-Barber L, Fairweather N, Eskola J, Dougan G. Influence of codon usage on the immunogenicity of a DNA vaccine against tetanus. Vaccine. 2000; 19:810-815. [PubMed: 11115703]

Su Z, Dannull J, Yang BK, Dahm P, Coleman D, Yancey D, Sichi S, Niedzwiecki D, Boczkowski D, Gilboa E, Vieweg J. Telomerase mRNA-transfected dendritic cells stimulate antigen-specific CD8+ and CD4+ T cell responses in patients with metastatic prostate cancer. J Immunol. 2005; 174:3798-3807. [PubMed: 15749921]

Subjeck JR, Shyy TT. Stress protein systems of mammalian cells. Am J Physiol. 1986; 250:C1-17. [PubMed: 3510555]

Tamura Y, Peng P, Liu K, Daou M, Srivastava PK. Immunotherapy of tumors with autologous tumorderived heat shock protein preparations. Science. 1997; 278:117-120. [PubMed: 9311915]

Tcherepanova IY, Adams MD, Feng X, Hinohara A, Horvatinovich J, Calderhead D, Healey D, Nicolette CA. Ectopic expression of a truncated CD40L protein from synthetic posttranscriptionally capped RNA in dendritic cells induces high levels of IL-12 secretion. BMC Mol Biol. 2008; 9:90. [PubMed: 18928538]

Tesniere A, Schlemmer F, Boige V, Kepp O, Martins I, Ghiringhelli F, Aymeric L, Michaud M, Apetoh L, Barault L, Mendiboure J, Pignon JP, Jooste V, van Endert P, Ducreux M, Zitvogel L, Piard F, Kroemer G. Immunogenic death of colon cancer cells treated with oxaliplatin. Oncogene. 2010; 29:482-491. [PubMed: 19881547]

Testori A, Richards J, Whitman E, Mann GB, Lutzky J, Camacho L, Parmiani G, Tosti G, Kirkwood JM, Hoos A, Yuh L, Gupta R, Srivastava PK. Phase III comparison of vitespen, an autologous tumor-derived heat shock protein gp96 peptide complex vaccine, with physician's choice of treatment for stage IV melanoma: the C-100-21 Study Group. J Clin Oncol. 2008; 26:955-962. [PubMed: 18281670]

Therasse P, Eisenhauer EA, Verweij J. RECIST revisited: a review of validation studies on tumour assessment. European journal of cancer. 2006; 42:1031-1039. [PubMed: 16616487]

Theriault JR, Adachi H, Calderwood SK. Role of scavenger receptors in the binding and internalization of heat shock protein 70. J Immunol. 2006; 177:8604-8611. [PubMed: 17142759]

Thurner B, Haendle I, Roder C, Dieckmann D, Keikavoussi P, Jonuleit H, Bender A, Maczek C, Schreiner D, von den Driesch P, Brocker EB, Steinman RM, Enk A, Kampgen E, Schuler G. Vaccination with mage-3A1 peptide-pulsed mature, monocyte-derived dendritic cells expands 
specific cytotoxic T cells and induces regression of some metastases in advanced stage IV melanoma. J Exp Med. 1999; 190:1669-1678. [PubMed: 10587357]

Timmerman JM, Levy R. Dendritic cell vaccines for cancer immunotherapy. Annu Rev Med. 1999; 50:507-529. [PubMed: 10073291]

Todryk SM, Melcher AA, Dalgleish AG, Vile RG. Heat shock proteins refine the danger theory. Immunology. 2000; 99:334-337. [PubMed: 10712661]

Tsang KY, Zaremba S, Nieroda CA, Zhu MZ, Hamilton JM, Schlom J. Generation of human cytotoxic $\mathrm{T}$ cells specific for human carcinoembryonic antigen epitopes from patients immunized with recombinant vaccinia-CEA vaccine. J Natl Cancer Inst. 1995; 87:982-990. [PubMed: 7629885]

Tuyaerts S, Aerts JL, Corthals J, Neyns B, Heirman C, Breckpot K, Thielemans K, Bonehill A. Current approaches in dendritic cell generation and future implications for cancer immunotherapy. Cancer immunology, immunotherapy : CII. 2007; 56:1513-1537.

Udono H, Levey DL, Srivastava PK. Cellular requirements for tumor-specific immunity elicited by heat shock proteins: tumor rejection antigen gp96 primes CD8+ T cells in vivo. Proc Natl Acad Sci U S A. 1994; 91:3077-3081. [PubMed: 7909157]

Uehori J, Matsumoto M, Tsuji S, Akazawa T, Takeuchi O, Akira S, Kawata T, Azuma I, Toyoshima K, Seya T. Simultaneous blocking of human Toll-like receptors 2 and 4 suppresses myeloid dendritic cell activation induced by Mycobacterium bovis bacillus Calmette-Guerin peptidoglycan. Infection and immunity. 2003; 71:4238-4249. [PubMed: 12874299]

van den Eertwegh AJ, Versluis J, van den Berg HP, Santegoets SJ, van Moorselaar RJ, van der Sluis TM, Gall HE, Harding TC, Jooss K, Lowy I, Pinedo HM, Scheper RJ, Stam AG, von Blomberg BM, de Gruijl TD, Hege K, Sacks N, Gerritsen WR. Combined immunotherapy with granulocyte-macrophage colony-stimulating factor-transduced allogeneic prostate cancer cells and ipilimumab in patients with metastatic castration-resistant prostate cancer: a phase 1 doseescalation trial. The lancet oncology. 2012; 13:509-517. [PubMed: 22326922]

van der Bruggen P, Traversari C, Chomez P, Lurquin C, De Plaen E, Van den Eynde B, Knuth A, Boon T. A gene encoding an antigen recognized by cytolytic T lymphocytes on a human melanoma. Science. 1991; 254:1643-1647. [PubMed: 1840703]

van der Meijden AP, Sylvester RJ, Oosterlinck W, Hoeltl W, Bono AV. Maintenance Bacillus Calmette-Guerin for Ta T1 bladder tumors is not associated with increased toxicity: results from a European Organisation for Research and Treatment of Cancer Genito-Urinary Group Phase III Trial. Eur Urol. 2003; 44:429-434. [PubMed: 14499676]

van Elsas A, Hurwitz AA, Allison JP. Combination immunotherapy of B16 melanoma using anticytotoxic T lymphocyte-associated antigen 4 (CTLA-4) and granulocyte/macrophage colonystimulating factor (GM-CSF)-producing vaccines induces rejection of subcutaneous and metastatic tumors accompanied by autoimmune depigmentation. J Exp Med. 1999; 190:355-366. [PubMed: 10430624]

Vanaja DK, Grossmann ME, Celis E, Young CY. Tumor prevention and antitumor immunity with heat shock protein 70 induced by 15-deoxy-delta12,14-prostaglandin $\mathrm{J} 2$ in transgenic adenocarcinoma of mouse prostate cells. Cancer Res. 2000; 60:4714-4718. [PubMed: 10987274]

Vergati M, Cereda V, Madan RA, Gulley JL, Huen NY, Rogers CJ, Hance KW, Arlen PM, Schlom J, Tsang KY. Analysis of circulating regulatory T cells in patients with metastatic prostate cancer pre- versus post-vaccination. Cancer immunology, immunotherapy : CII. 2011; 60:197-206.

Vesely MD, Kershaw MH, Schreiber RD, Smyth MJ. Natural innate and adaptive immunity to cancer. Annual review of immunology. 2011; 29:235-271.

Vignali DA, Collison LW, Workman CJ. How regulatory T cells work. Nature reviews. Immunology. 2008; 8:523-532. [PubMed: 18566595]

von Mehren M, Arlen P, Gulley J, Rogatko A, Cooper HS, Meropol NJ, Alpaugh RK, Davey M, McLaughlin S, Beard MT, Tsang KY, Schlom J, Weiner LM. The influence of granulocyte macrophage colony-stimulating factor and prior chemotherapy on the immunological response to a vaccine (ALVAC-CEA B7.1) in patients with metastatic carcinoma. Clinical cancer research : an official journal of the American Association for Cancer Research. 2001; 7:1181-1191. [PubMed: 11350882] 
Vonderheide RH, Hahn WC, Schultze JL, Nadler LM. The telomerase catalytic subunit is a widely expressed tumor-associated antigen recognized by cytotoxic T lymphocytes. Immunity. 1999; 10:673-679. [PubMed: 10403642]

Wakimoto H, Abe J, Tsunoda R, Aoyagi M, Hirakawa K, Hamada H. Intensified antitumor immunity by a cancer vaccine that produces granulocyte-macrophage colony-stimulating factor plus interleukin 4. Cancer research. 1996; 56:1828-1833. [PubMed: 8620500]

Walsh SR, Dolin R. Vaccinia viruses: vaccines against smallpox and vectors against infectious diseases and tumors. Expert review of vaccines. 2011; 10:1221-1240. [PubMed: 21854314]

Walter P, Johnson AE. Signal sequence recognition and protein targeting to the endoplasmic reticulum membrane. Annu Rev Cell Biol. 1994; 10:87-119. [PubMed: 7888184]

Wang B, Zaidi N, He LZ, Zhang L, Kuroiwa JM, Keler T, Steinman RM. Targeting of the nonmutated tumor antigen HER2/neu to mature dendritic cells induces an integrated immune response that protects against breast cancer in mice. Breast Cancer Res. 2012; 14:R39. [PubMed: 22397502]

Wang, X-Y.; Easton, DP.; Subjeck, JR. Large mammalian hsp70 family proteins, hsp110 and grp170, and their roles in biology and cancer therapy. Springer; New York: 2007a.

Wang XY, Arnouk H, Chen X, Kazim L, Repasky EA, Subjeck JR. Extracellular targeting of endoplasmic reticulum chaperone glucose-regulated protein 170 enhances tumor immunity to a poorly immunogenic melanoma. J Immunol. 2006a; 177:1543-1551. [PubMed: 16849461]

Wang XY, Chen X, Manjili MH, Repasky E, Henderson R, Subjeck JR. Targeted immunotherapy using reconstituted chaperone complexes of heat shock protein 110 and melanoma-associated antigen gp100. Cancer Res. 2003; 63:2553-2560. [PubMed: 12750279]

Wang XY, Facciponte J, Chen X, Subjeck JR, Repasky EA. Scavenger receptor-A negatively regulates antitumor immunity. Cancer Res. 2007b; 67:4996-5002. [PubMed: 17510431]

Wang XY, Facciponte JG, Subjeck JR. Molecular chaperones and cancer immunotherapy. Handb Exp Pharmacol. 2006b; 172:305-329. [PubMed: 16610365]

Wang XY, Kazim L, Repasky EA, Subjeck JR. Characterization of heat shock protein 110 and glucose-regulated protein 170 as cancer vaccines and the effect of fever-range hyperthermia on vaccine activity. J Immunol. 2001; 166:490-497. [PubMed: 11123328]

Wang XY, Sun X, Chen X, Facciponte J, Repasky EA, Kane J, Subjeck JR. Superior antitumor response induced by large stress protein chaperoned protein antigen compared with peptide antigen. J Immunol. 2010; 184:6309-6319. [PubMed: 20439916]

Wang XY, Zuo D, Sarkar D, Fisher PB. Blockade of cytotoxic T-lymphocyte antigen-4 as a new therapeutic approach for advanced melanoma. Expert Opin Pharmacother. 2011a; 12:2695-2706. [PubMed: 22077831]

Wang Y, Wang XY, Subjeck JR, Shrikant PA, Kim HL. Temsirolimus, an mTOR inhibitor, enhances anti-tumour effects of heat shock protein cancer vaccines. Br J Cancer. 2011b; 104:643-652. [PubMed: 21285988]

Wansley EK, Chakraborty M, Hance KW, Bernstein MB, Boehm AL, Guo Z, Quick D, Franzusoff A, Greiner JW, Schlom J, Hodge JW. Vaccination with a recombinant Saccharomyces cerevisiae expressing a tumor antigen breaks immune tolerance and elicits therapeutic antitumor responses. Clinical cancer research : an official journal of the American Association for Cancer Research. 2008; 14:4316-4325. [PubMed: 18594015]

Weber JS, Vogelzang NJ, Ernstoff MS, Goodman OB, Cranmer LD, Marshall JL, Miles S, Rosario D, Diamond DC, Qiu Z, Obrocea M, Bot A. A phase 1 study of a vaccine targeting preferentially expressed antigen in melanoma and prostate-specific membrane antigen in patients with advanced solid tumors. J Immunother. 2011; 34:556-567. [PubMed: 21760528]

Wei H, Wang S, Zhang D, Hou S, Qian W, Li B, Guo H, Kou G, He J, Wang H, Guo Y. Targeted delivery of tumor antigens to activated dendritic cells via CD11c molecules induces potent antitumor immunity in mice. Clin Cancer Res. 2009; 15:4612-4621. [PubMed: 19584156]

Weide B, Carralot JP, Reese A, Scheel B, Eigentler TK, Hoerr I, Rammensee HG, Garbe C, Pascolo S. Results of the first phase I/II clinical vaccination trial with direct injection of mRNA. J Immunother. 2008; 31:180-188. [PubMed: 18481387] 
Weide B, Pascolo S, Scheel B, Derhovanessian E, Pflugfelder A, Eigentler TK, Pawelec G, Hoerr I, Rammensee HG, Garbe C. Direct injection of protamine-protected mRNA: results of a phase $1 / 2$ vaccination trial in metastatic melanoma patients. J Immunother. 2009; 32:498-507. [PubMed: 19609242]

Welch WJ. Heat shock proteins functioning as molecular chaperones: their roles in normal and stressed cells. Philos Trans R Soc Lond B Biol Sci. 1993; 339:327-333. [PubMed: 8098537]

Wille-Reece U, Flynn BJ, Lore K, Koup RA, Miles AP, Saul A, Kedl RM, Mattapallil JJ, Weiss WR, Roederer M, Seder RA. Toll-like receptor agonists influence the magnitude and quality of memory $\mathrm{T}$ cell responses after prime-boost immunization in nonhuman primates. J. Exp. Med. 2006; 203:1249-1258. [PubMed: 16636134]

Wolchok JD, Hoos A, O'Day S, Weber JS, Hamid O, Lebbe C, Maio M, Binder M, Bohnsack O, Nichol G, Humphrey R, Hodi FS. Guidelines for the evaluation of immune therapy activity in solid tumors: immune-related response criteria. Clin Cancer Res. 2009; 15:7412-7420. [PubMed: 19934295]

Wolchok JD, Yang AS, Weber JS. Immune regulatory antibodies: are they the next advance? Cancer J. 2010; 16:311-317. [PubMed: 20693841]

Wolff JA, Malone RW, Williams P, Chong W, Acsadi G, Jani A, Felgner PL. Direct gene transfer into mouse muscle in vivo. Science. 1990; 247:1465-1468. [PubMed: 1690918]

Wolkers MC, Toebes M, Okabe M, Haanen JB, Schumacher TN. Optimizing the efficacy of epitopedirected DNA vaccination. Journal of immunology. 2002; 168:4998-5004.

Wood C, Srivastava P, Bukowski R, Lacombe L, Gorelov AI, Gorelov S, Mulders P, Zielinski H, Hoos A, Teofilovici F, Isakov L, Flanigan R, Figlin R, Gupta R, Escudier B. An adjuvant autologous therapeutic vaccine (HSPPC-96; vitespen) versus observation alone for patients at high risk of recurrence after nephrectomy for renal cell carcinoma: a multicentre, open-label, randomised phase III trial. Lancet. 2008; 372:145-154. [PubMed: 18602688]

Xiang R, Luo Y, Niethammer AG, Reisfeld RA. Oral DNA vaccines target the tumor vasculature and microenvironment and suppress tumor growth and metastasis. Immunol Rev. 2008; 222:117128. [PubMed: 18363997]

Yang JC. Vitespen: a vaccine for renal cancer? Lancet. 2008; 372:92-93. [PubMed: 18602687]

Yedavelli SP, Guo L, Daou ME, Srivastava PK, Mittelman A, Tiwari RK. Preventive and therapeutic effect of tumor derived heat shock protein, gp96, in an experimental prostate cancer model. Int J Mol Med. 1999; 4:243-248. [PubMed: 10425272]

Yi H, Guo C, Yu X, Gao P, Qian J, Zuo D, Manjili MH, Fisher PB, Subjeck JR, Wang XY. Targeting the immunoregulator SRA/CD204 potentiates specific dendritic cell vaccine-induced $T$ cell response and antitumor immunity. Cancer Res. 2011; 71:6611-6620. [PubMed: 21914786]

Yi H, Yu X, Gao P, Wang Y, Baek SH, Chen X, Kim HL, Subjeck JR, Wang XY. Pattern recognition scavenger receptor SRA/CD204 down-regulates Toll-like receptor 4 signaling-dependent CD8 Tcell activation. Blood. 2009; 113:5819-5828. [PubMed: 19349620]

Yi H, Zuo D, Yu X, Hu F, Manjili MH, Chen Z, Subjeck JR, Wang XY. Suppression of antigenspecific CD4(+) T cell activation by SRA/CD204 through reducing the immunostimulatory capability of antigen-presenting cell. Journal of molecular medicine. 2012; 90:413-426. [PubMed: 22083206]

Ying H, Zaks TZ, Wang RF, Irvine KR, Kammula US, Marincola FM, Leitner WW, Restifo NP. Cancer therapy using a self-replicating RNA vaccine. Nat Med. 1999; 5:823-827. [PubMed: 10395329]

Youn JI, Nagaraj S, Collazo M, Gabrilovich DI. Subsets of myeloid-derived suppressor cells in tumorbearing mice. J Immunol. 2008; 181:5791-5802. [PubMed: 18832739]

Younes A. A phase II study of heat shock protein-peptide complex-96 vaccine therapy in patients with indolent non-Hodgkin's lymphoma. Clin Lymphoma. 2003; 4:183-185. [PubMed: 14715102]

Yu JS, Wheeler CJ, Zeltzer PM, Ying H, Finger DN, Lee PK, Yong WH, Incardona F, Thompson RC, Riedinger MS, Zhang W, Prins RM, Black KL. Vaccination of malignant glioma patients with peptide-pulsed dendritic cells elicits systemic cytotoxicity and intracranial T-cell infiltration. Cancer Res. 2001; 61:842-847. [PubMed: 11221866] 
Yu X, Yi H, Guo C, Zuo D, Wang Y, Kim HL, Subjeck JR, Wang XY. Pattern recognition scavenger receptor CD204 attenuates Toll-like receptor 4-induced NF-kappaB activation by directly inhibiting ubiquitination of tumor necrosis factor (TNF) receptor-associated factor 6. J Biol Chem. 2011; 286:18795-18806. [PubMed: 21460221]

Yuan J, Gnjatic S, Li H, Powel S, Gallardo HF, Ritter E, Ku GY, Jungbluth AA, Segal NH, Rasalan TS, Manukian G, Xu Y, Roman RA, Terzulli SL, Heywood M, Pogoriler E, Ritter G, Old LJ, Allison JP, Wolchok JD. CTLA-4 blockade enhances polyfunctional NY-ESO-1 specific T cell responses in metastatic melanoma patients with clinical benefit. Proc Natl Acad Sci U S A. 2008; 105:20410-20415. [PubMed: 19074257]

Zhou G, Drake CG, Levitsky HI. Amplification of tumor-specific regulatory T cells following therapeutic cancer vaccines. Blood. 2006; 107:628-636. [PubMed: 16179369]

Zhou G, Levitsky H. Towards curative cancer immunotherapy: overcoming posttherapy tumor escape. Clin Dev Immunol. 2012; 2012:124187. [PubMed: 22778760]

Zhou G, Levitsky HI. Natural regulatory T cells and de novo-induced regulatory T cells contribute independently to tumor-specific tolerance. Journal of immunology. 2007; 178:2155-2162.

Zitvogel L, Kepp O, Senovilla L, Menger L, Chaput N, Kroemer G. Immunogenic tumor cell death for optimal anticancer therapy: the calreticulin exposure pathway. Clin Cancer Res. 2010; 16:31003104. [PubMed: 20421432] 


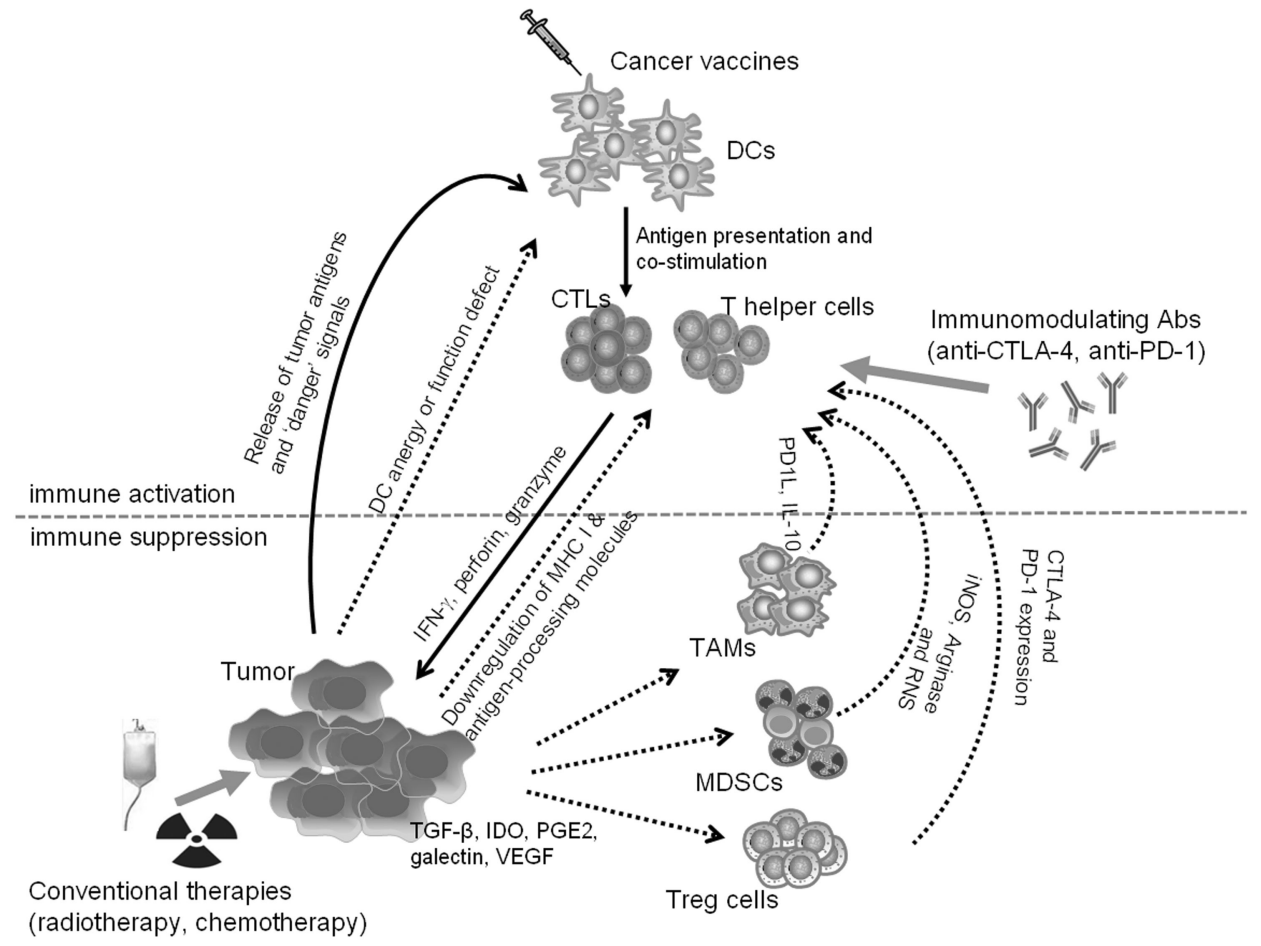

Figure 1. Counteracting tumor-induced immune suppression to achieve effective cancer vaccine therapy

Active immunization with therapeutic vaccines generally targets the host DCs for effective presentation of tumor-associated antigens and subsequent priming of $\mathrm{CD} 8^{+} \mathrm{CTLs}$ and $\mathrm{CD} 4^{+}$ $\mathrm{T}$ helper cells. These tumor-specific T effector cells together with other innate immune cells can result in inhibition or destruction of cancer cells. In the tumor microenvironment, cancer cells produce immunosuppressive soluble factors (TGF- $\beta$, IL-10, IDO, galectin and VEGF) and expand or recruit immune regulatory cells (MDSCs, Tregs and TAMs), which establish an immunosuppressive state at the tumor site. This complex molecular and cellular network attenuates vaccine-induced antitumor immune responses and promotes tumor escape from immune attack. To overcome the immune suppressive mechanisms, novel immune modulators (anti-CTLA-4 and anti-PD1 antibodies) may be used to enhance vaccine potency and restore durable antitumor immunity. Cancer vaccines can also be combined with conventional cancer treatments, such as radiotherapy and chemotherapy, to engage multivalent antitumor effects for optimized therapeutic efficacy. 
Table 1

Ongoing phase III trials of therapeutic cancer vaccines

\begin{tabular}{|c|c|c|c|c|}
\hline Vaccines & & Description & Cancer type & NCI ID \\
\hline \multirow{3}{*}{ DC/APCs } & AGS-003 & $\begin{array}{l}\text { autologous DCs transfected with tumor and CD40L } \\
\text { RNAs }\end{array}$ & RCC & NCT01582672 \\
\hline & DCVax®-L & autologous DCs loaded with tumor lysate & GBM & NCT00045968 \\
\hline & Cvac & $\begin{array}{l}\text { autologous DCs pulsed with MUC1-mannan fusion } \\
\text { protein }\end{array}$ & EOC & NCT01521143 \\
\hline \multirow{7}{*}{ Peptides/proteins } & GV1001 & hTERT peptide & NSCLC & NCT01579188 \\
\hline & GV1001 & hTERT peptide & Pancreatic Cancer & NCT00425360 \\
\hline & NeuVax ${ }^{\mathrm{TM}}$ & HER2/neu peptide combined with GM-CSF & Breast Cancer & NCT01479244 \\
\hline & N/A & $\begin{array}{l}\text { MAGE-A3 and NY-ESO-1 peptides combined with GM- } \\
\text { CSF }\end{array}$ & Multiple Myeloma & NCT00090493 \\
\hline & Stimuvax & $\begin{array}{l}\text { liposome-encapsulated synthetic peptide derived from } \\
\text { MUC-1 }\end{array}$ & NSCLC & NCT01015443 \\
\hline & Rindopepimut & hEGFR variant III specific peptide conjugated to KLH & GBM & NCT01480479 \\
\hline & POL-103A & $\begin{array}{l}\text { protein antigens from } 3 \text { melanoma cell lines with alum } \\
\text { adjuvant }\end{array}$ & Melanoma & NCT01546571 \\
\hline \multirow{5}{*}{ Virus vectors } & PROSTVAC & $\begin{array}{l}\text { recombinant fowlpox/vaccinia virus encoding hPSA and } \\
\text { TRICOM }\end{array}$ & Metastatic Prostate Cancer & NCT01322490 \\
\hline & CG0070 & oncolytic adenovirus encoding GM-CSF & Bladder Cancer & NCT01438112 \\
\hline & INGN 201 & adenovirus encoding p53 & SCCHN & NCT00041613 \\
\hline & INGN 201 & $\begin{array}{l}\text { adenovirus encoding p } 53 \text { combined with cisplatin and } \\
\text { fluorouracil }\end{array}$ & SCCHN & NCT00041626 \\
\hline & TG4010 & modified vaccinia virus encoding human MUC1 and IL-2 & NSCLC & NCT01383148 \\
\hline
\end{tabular}

EGFR, epidermal growth factor receptor; EOC, epithelial ovarian cancer; GBM, glioblastoma; GM-CSF, granulocyte-macrophage colonystimulating factor; hPSA, human prostate specific antigen; hTERT, human telomerase reverse transcriptase; KLH, keyhole limpet hemocyanin; MUC1, mucin 1; NSCLC, non-small cell lung cancer; RCC, renal cell carcinoma; SCCHN, squamous cell cancer of the head and neck; TRICOM, recombinant vaccinia virus vaccine encoding three co-stimulatory molecule transgenes B7.1, ICAM-1, and LFA-3. 